\title{
Inflation Targeting in India: Issues and Prospects ${ }^{*}$
}

\author{
Raghbendra Jha
}

\begin{abstract}
Inflation targeting (henceforth IT) has emerged as a significant monetary policy framework in both developed and transition economies. It has been in place for a decade or more in a number of countries - with around 20 central banks adopting it as their basic monetary policy framework. Some authors have argued that for transition economies undergoing sustained financial liberalization and integration in world financial markets IT is an attractive monetary policy framework. Consequently there is some pressure for such economies to adopt IT as a core element in their monetary policy frameworks.

The present paper evaluates the case for IT in India. It begins with stating, almost from first principles, the objectives of monetary policy in India. I argue that inflation control cannot be an exclusive concern of monetary policy in a country such as India with a substantial poverty problem. The rationales for IT is then spelt out as are some nuances of the practical implementation of IT. The paper provides some evidence on the effects of IT in developed and transition economies and argues that although IT may have been responsible for maintaining a low inflation regime it has not brought down the inflation rate itself substantially. Further, the volatility of exchange rate and output movements in transition countries adopting IT has been higher than in developed market economies. The paper then discusses India's experience with using rules-based policy measures (nominal targets) and elaborates on the reasons (as espoused in the extant literature) why India is not ready for IT. It is further shown that even if the Reserve Bank of India wanted to, it could not pursue IT since the short-term interest rate (the principal policy tool used to affect inflation in countries working with IT) does not have significant effects on the rate of inflation. The paper concludes by listing monetary policy options for India at the current time.
\end{abstract}

All correspondence to:

Prof. Raghbendra Jha, ASARC, Division of Economics, Research School of Pacific and Studies, Australian National University, Canberra, ACT 0200, Australia.

Phone: + 61261252683

Fax: + 61261250443

Email: r.jha@anu.edu.au

\footnotetext{
* I am grateful to Gerald Epstein for helpful discussions and Anurag Sharma for research assistance. The usual disclaimer applies.
} 


\section{Introduction}

Inflation targeting (henceforth IT) has emerged as a significant monetary policy framework in both developed and transition economies. It has been in place for a decade or more in a number of countries - with around 20 central banks adopting it as their basic monetary policy framework.

Over time IT has evolved across a number of dimensions, including its degree of flexibility and approaches to communication. Some early adopters have shown greater flexibility by allowing inflation to vary more widely around the target range and, in some cases, some other macroeconomic goals to be taken into account. Central banks have also enhanced their communication with their respective publics about their targets and modus operandi.

Some authors have argued that for transition economies undergoing sustained financial liberalization and integration in world financial markets IT is an attractive monetary policy framework. Consequently there is some pressure for such economies to adopt IT as a core element in their monetary policy frameworks.

The present paper evaluates the case for IT in India. It begins (in section II) with stating, almost from first principles, the objectives of monetary policy in India. I argue that inflation control cannot be an exclusive concern of monetary policy in a country such as India with a substantial poverty problem. The rationale for IT is spelt out in section III of the paper. This section also develops some nuances of the practical implementation of IT. Section IV provides some evidence on the effects of IT in developed and transition economies and argues that, although IT may have been responsible for maintaining a low inflation regime, it has not brought down the inflation rate itself substantially. Further, the volatility of exchange rate and output 
movements in transition countries adopting IT has been higher than in developed market economies. Section V discusses India’s experience with using rules-based policy measures (nominal targets) whereas section VI discusses some recent developments in the development of monetary policy in India. Section VII reviews the reasons (as espoused in the extant literature) why India is not ready for IT. Section VIII develops this these further by arguing that, even if the Reserve Bank of India wanted to, it could not pursue IT since the short-term interest rate (the principal policy tool used to affect inflation in countries working with IT) does not have significant effects on the rate of inflation. Section IX reviews monetary policy options for India and concludes.

\section{The Objectives of Monetary Policy in India}

By popular consensus an overriding short-term concern of monetary policy is stabilization of the price level. However, since India has long had a serious problem of poverty, its alleviation has to be the cornerstone of the success of any policy including monetary policy. There is substantial agreement now that the most important factor responsible for reduction in poverty is rapid economic growth along with some supporting redistributive measures. Dollar and Kraay (2001) show for a broad cross section of countries including India, that the incomes of the poorest 20 per cent of the population rise in proportion to average income. ${ }^{1}$ Furthermore, growth seems to matter more than factors such as governance. The overwhelming importance of economic growth to poverty reduction can be illustrated with Chinese data (Table 1).

\footnotetext{
${ }^{1}$ Even if the Dollar-Kraay result is discounted because of the well-known problems associated with cross-country regressions, at the very least there is no evidence that economic growth hurts poverty alleviation (Winters et al. 2002).
} 
Table 1: Growth and Poverty Alleviation in China

\begin{tabular}{|l|c|c|c|c|}
\hline Year & $\begin{array}{c}\text { Annual poverty } \\
\text { reduction announced } \\
\text { by the government (10 } \\
\text { thousand) }\end{array}$ & $\begin{array}{c}\text { The growth rate of } \\
\text { GDP } \\
\text { per capita } \\
(\%)\end{array}$ & $\begin{array}{c}\text { The growth rate of } \\
\text { farmers' consumption } \\
\text { level } \\
(\%)\end{array}$ & $\begin{array}{c}\text { The growth rate of } \\
\text { farmers' } \\
\text { net income } \\
\text { per capita } \\
(\%)\end{array}$ \\
\hline $1978-1985$ & 1786 & 8.3 & 10.0 & 15.1 \\
\hline $1985-1990$ & 800 & 6.2 & 2.5 & 3.0 \\
\hline $1990-1997$ & 500 & 9.9 & 8.0 & 5.0 \\
\hline $1997-2002$ & 436 & 7.7 & 3.4 & 3.8 \\
\hline $1978-2002$ & 924 & 8.1 & 5.6 & 7.2 \\
\hline
\end{tabular}

Source: Chinese Statistical Abstract, various issues.

For more than 26 years the Chinese per capita GDP has grown at more than 8 per cent per annum. Poverty has declined at an average of 9,240,000 persons per year.

It is instructive to compare the growth performance of the Chinese economy with that of India. Data on GDP and per-capita growth in India are presented in Table 2.

Table 2: GDP and Per Capita GDP growth in India

\begin{tabular}{|l|c|c|}
\hline & \multicolumn{2}{|c|}{ GDP growth (\%) } \\
\hline Period & Aggregate & Per-capita \\
\hline $1972-1982$ & 3.5 & 1.2 \\
\hline $1982-1992$ & 5.2 & 3.0 \\
\hline $1992-2002$ & 6.0 & 3.9 \\
\hline
\end{tabular}

Source: Kelkar (2004)

Clearly, the Indian growth experience does not match China’s. Hence, the reduction in poverty in India has been nowhere as spectacular as in China, despite the fact that inequality in China has grown more sharply than in India (Jha, 2004). India’s national poverty headcount ratio fell only by about 12 percentage points over the 46-year 
period $1951-52$ to $1997^{2}$ and the rate of poverty reduction was higher in the $1980 \mathrm{~s}$ than in the reform period, post 1991. Hence, two important conclusions emerge from an analysis of the Indian data. First, economic growth in India has not been high enough to drastically reduce the incidence of poverty. Second, the quality of growth in the 1980s was different from that in the 1990s, so that even with (slightly) lower growth a greater reduction in poverty could take place in the earlier period. ${ }^{3}$

To put it bluntly, the $9^{\text {th }}$ Five-year Plan document of the Planning Commission of the Government of India estimated that Indian GDP would need to grow at 7 per cent ${ }^{4}$ or more to absorb the current unemployed and the anticipated increment to the labour force. However, the Indian economy is as yet unable to achieve a trend rate of growth of 7 per cent and the Ninth Five-Year Plan's target to create 54 million new jobs during the Plan period (1997-2002) has not been fulfilled. Hence, at the margin the unemployment problem is getting steadily worse. ${ }^{5}$ I present data on employment and unemployment using this criterion (in Table 3). The notion of employment used is that of Current Daily Status (CDS), as this measure of employment is net of the varying degrees of unemployment experienced by those who are otherwise classified as employed on usual status basis.

\footnotetext{
${ }^{2}$ Results from the 1999-2000 National Sample Survey show a larger drop in poverty; however, this Survey's methodology does not match those of the earlier surveys. Once corrections for the change in methodology are made the drop in poverty turns out to be modest.

${ }^{3} \mathrm{~A}$ third conclusion, not indicated in the analysis above, is that the incidence of poverty is getting regionally concentrated (Jha, 2004).

${ }^{4}$ On 6 April 2005, while assessing the mid-term progress of the Tenth Five year Plan Indian Prime Minister Manmohan Singh ruled out the Indian economy attaining 7 per cent growth rate during the next two years.

${ }^{5}$ According to a study on employment conditions by the Planning Commission of India, unemployment is likely to have risen to 9.2 per cent in F2002 (base year for the country's tenth five-year plan) from 7.3 per cent in F2000. As per this study, the unemployment rate at the end of the tenth five-year plan (F2003-F2007) is likely to rise to 11 per cent (45 million), even if average G cent growth rate during the next two years. DP growth of 6.5 per cent is achieved during the plan period. With the increase in GDP in the first three years of the plan period averaging 6.1 per cent, growth needs to accelerate to an average of 7.1 per cent in F2006 and F2007 to achieve the average of 6.5 per cent in the plan period. This, in our opinion, is optimistic. Hence, there is a high chance that unemployment will be higher than the official estimate of 11 per cent by F2007. On 8 April 2005 the Prime Minster noted that GDP growth during the next two years is not likely to reach 7 per cent, even on average.
} 
Table 3: Employment and Unemployment on Current Daily Status (CDS) Basis

\begin{tabular}{|c|c|c|c|c|c|}
\hline & \multicolumn{3}{|c|}{ (Million) } & \multicolumn{2}{|c|}{ Growth per annum (\%) } \\
\hline & 1983 & 1993-94 & 1999-2000 & 1983 to $1993-94$ & $\begin{array}{l}1993-94 \text { to } \\
1999-2000\end{array}$ \\
\hline & \multicolumn{5}{|c|}{ All India } \\
\hline Population & 718.20 & 894.01 & 1003.97 & 2.0 & 1.95 \\
\hline Labour Force & 261.33 & 335.97 & 363.33 & 2.43 & 1.31 \\
\hline Workforce & 239.57 & 315.84 & 336.75 & 2.70 & 1.07 \\
\hline Unemployment Rate (\%) & 8.30 & 5.99 & 7.32 & & \\
\hline \multirow[t]{2}{*}{ Number unemployed } & 21.76 & 20.13 & 26.58 & -0.08 & 4.74 \\
\hline & \multicolumn{5}{|c|}{ Rural } \\
\hline Population & 546.61 & 658.83 & 727.50 & 1.79 & 1.67 \\
\hline Labour Force & 204.18 & 255.38 & 270.39 & 2.15 & 0.96 \\
\hline Workforce & 187.92 & 241.04 & 250.89 & 2.40 & 0.67 \\
\hline Unemployment Rate (\%) & 7.96 & 5.61 & 7.21 & & \\
\hline \multirow[t]{2}{*}{ Number unemployed } & 16.26 & 14.34 & 19.50 & -1.19 & 5.26 \\
\hline & \multicolumn{5}{|c|}{ Urban } \\
\hline Population & 171.59 & 234.98 & 276.47 & 3.04 & 2.74 \\
\hline Labour Force & 57.15 & 80.60 & 92.95 & 3.33 & 2.40 \\
\hline Workforce & 51.64 & 74.80 & 85.84 & 3.59 & 2.32 \\
\hline Unemployment Rate (\%) & 9.64 & 7.19 & 7.65 & & \\
\hline Number unemployed & 5.51 & 5.80 & 7.11 & 0.49 & 3.45 \\
\hline
\end{tabular}

Source: Economic Survey, Government of India, 2002-03

Table 3 shows that employment growth fell sharply in the 1990s. Both the absolute number of unemployed as well as the incidence of unemployment (expressed in terms of unemployed as a percentage of the labour force) increased during this period. The decline in the rate of growth of employment was associated with a sharp decline in the rate of growth of the labour force (indicating delayed entry into the labour force through longer training/education).

In addition to open unemployment there also exists India’s persistent problem of underemployment. Underemployment in various segments of the labour force is quite high. The estimates of the $50^{\text {th }}$ Round of the NSS indicate that 
although open unemployment was only 2 per cent in 1993-94 on a 'usual status' basis, the incidence of under-employment and unemployment taken together was as much as 10 per cent that year. This occurred despite the fact that the incidence of underemployment was reduced substantially in the decade ending 1993-94.

In the organised sector (even in the organised manufacturing sector), employment barely changed between 1991 and 2001; from 1997 it has actually fallen. Data from the National Sample Survey indicate that total employment (organised and unorganised) is growing at about 1 per cent per annum. This is half the projected growth rate of the labour force. ${ }^{6}$

It is obvious that if India is to reduce poverty rapidly, it is imperative to raise the trend rate of growth from near 6 per cent per year to 8 per cent or more. India's current growth rate, although high by current international standards, is not adequate to ensure speedy elimination of poverty and unemployment in India. Some authors such as Kelkar (2004) have opined that the current rate of growth could accelerate. Contributing to this acceleration is a broad series of reforms including financial sector reforms, increased globalization and widening and deepening of product and financial markets. Their impact gets reflected in key indicators such as market capitalization of the stock market, the technology and transparency of transactions, the sets of instruments traded, balance sheets of financial institutions and the degree of openness of the economy. At the same time a mildly benign FDI policy framework has permitted greater tie-ups in high technology areas for production for domestic as well

\footnotetext{
${ }^{6}$ In some quarters, it is thought that employment could grow rapidly on the back of exports of software services. But current employment in that sector is about 700 thousand; on optimistic assumptions, it may rise to 2 million by 2010. But India's labour force is set to grow by about 8 million per year for the next 20 years. Thus, it is most unlikely that India could grow fast without rapid growth in exports of labour-intensive manufactured goods. Maintaining a competitive exchange rate is one of several policy measures that are relevant for this purpose (others include trade liberalisation, labour market reform, abolition of small-scale reservations and provision of primary education). Note that the share of the manufacturing sector in India's GDP is only about 25 per cent and has not grown much in the past 40 years. In contrast the share of the manufacturing sector in the Chinese or other East Asian market economies has been in excess of 40 per cent.
} 
as external markets. Adding to the impetus for higher economic growth are certain structural changes — particularly on the supply side. In addition to the existing stock of 'surplus labour' India is set to reap an important demographic dividend. In 2000 the proportion of the Indian population in the working age group (15-64 age bracket) was 60.9 per cent. The UN's Population Division has projected that this ratio will surpass the proportion of Japanese in this age group by 2012 and climb to over 66 per cent in 30 years. At that time it is poised to overtake China's population in the same age. This will not only help to keep real wages down but also to raise the rate of private saving. Clearly India’s population is undergoing rapid structural transformation: the proportion of the working population is rising; the labour force is less nutritionally deprived and increasingly literate. These changes imply substantial quality improvements. Economic theory and international experience indicate that this could lead to sharp rises in labour productivity and an upward shift in the trend long run rate of growth of the Indian economy. There is a catch though. The labour force has to be productively employed for these productivity gains to be realized. In view of the fact that adequate employment opportunities are not forthcoming political support for the reforms program (that has made the high growth possible in the first place) has waned (Jha, 2005).

Hence a critical touchstone for the success of monetary policy must be whether it is able to provide a climate for even higher economic growth. In particular, monetary policy must thus be tuned to ensure that the inducement to invest is maintained at a high level (so that savings do not get wasted), which, in turn, would need a regime of low interest rates and high rates of exports of low value added manufacturing products. While the first would imply an increase in the 'safe limit' for monetary expansion (so that unsterilized interventions in response to balance of 
payments surpluses can play a larger role), the second would require the rupee to be slightly undervalued (to increase exports) and the exchange rate to have low volatility. Hence, an appropriate monetary policy for India must work towards low and stable interest rates and slightly undervalued exchange rate with low volatility.

The Reserve Bank of India (henceforth RBI) — India’s central bank — has explicitly laid down these as among the objective of its monetary policy. In 1998 the RBI formally adopted multiple objectives of monetary policy. These are (i) to maintain a stable inflation environment; (ii) to maintain appropriate liquidity conditions to support higher economic growth; (iii) to ensure orderly conditions in the exchange market; to avoid excessive volatility in the exchange rate; and (iv) to maintain a stable interest rate environment (RBI, 2002).

Before I examine whether, given these objective, inflation targeting is suitable for India it is useful to review the case for inflation targeting as espoused by its proponents.

\section{Rationale for IT}

The time inconsistency literature argues that a purely discretionary policy setting leads to higher long-run inflation (Kydland and Prescott, 1977; Barro and Gordon, 1983). ${ }^{7}$ In view of the high costs of inflation the prescription is for the central bank to adopt a rules-based policy to reduce the inflationary bias of discretionary monetary policy.

The preference for a rules based policy has led to the adoption of nominal targets by central banks ostensibly to bring greater credibility and transparency into central bank operations. Under a rules based regime central banks set explicit values

\footnotetext{
${ }^{7}$ Further, a discretionary policy does not lead to higher output (than a rules policy) in steady state.
} 
for intermediate targets, which they can control, and which are strongly related to the

ultimate goals of monetary (e.g., stabilization of output and inflation), which

monetary policy cannot directly control.

In recent times emerging market economies such as India have experimented

with three nominal targets at various times: exchange rate, money supply growth and inflation. $^{8}$ The relative advantages/disadvantages of exchange rate and money growth targeting are portrayed in Table 4.

Table 4: Advantages and Disadvantages of the Nominal Anchors of Exchange Rate Targeting and Monetary Targeting.

\begin{tabular}{|c|c|}
\hline & Anchor: Exchange Rate Targeting \\
\hline \multirow[t]{4}{*}{ Advantages } & $\begin{array}{l}\text { 1. This fixes the inflation rate for internationally traded goods and thus directly contributes to keeping } \\
\text { inflation under control. It is especially useful for sharply reducing inflation in emerging market } \\
\text { economies. }\end{array}$ \\
\hline & $\begin{array}{l}\text { 2. If the exchange rate peg is credible, it anchors inflation expectations to the inflation rate in the } \\
\text { anchor country to whose currency it is pegged. }\end{array}$ \\
\hline & $\begin{array}{l}\text { 3. An exchange rate provides an automatic rule for the conduct of monetary policy that avoids the } \\
\text { time-inconsistency problem. }\end{array}$ \\
\hline & 4. An exchange rate is simple and direct and, therefore, is well understood by the public. \\
\hline \multirow[t]{5}{*}{ Disadvantages } & $\begin{array}{l}\text { 1. An exchange rate target leads to loss of independent monetary policy (Obstfeld and Rogoff, 1996). } \\
\text { Hence the ability of the monetary authorities to respond to shocks is compromised. }\end{array}$ \\
\hline & $\begin{array}{l}\text { 2. The exchange rate peg may persuade large scale foreign borrowing. In the case of emerging } \\
\text { market economies such loans are invariably denominated in foreign currency. Large } \\
\text { accumulation of such loans may lead to a crisis. In most developed countries a devaluation may } \\
\text { have little direct effect on the balance sheets (since debts are denominated in home currency) } \\
\text { but not so in emerging market economies since debts are denominated in foreign currency. }\end{array}$ \\
\hline & 3. Bernanke and Mishkin (1997) argue that exchange rate pegs can lead to financial fragility. \\
\hline & $\begin{array}{l}\text { 4. Although exchange rate targeting may be initially successful in bringing inflation down a successful } \\
\text { speculative attack can lead to a resurgence of inflation. }\end{array}$ \\
\hline & Anchor: Monetary Targeting \\
\hline \multirow[t]{2}{*}{ Advantages } & $\begin{array}{l}\text { 1. An advantage over exchange rate targeting is that monetary targeting enables a central bank to } \\
\text { adjust its monetary policy to cope with domestic considerations. }\end{array}$ \\
\hline & $\begin{array}{l}\text { 2. A monetary target is easily understood by the public - but not as well as an exchange rate target. } \\
\text { 3. Monetary targets have the advantage of being able to promote almost immediate accountability for } \\
\text { monetary policy. }\end{array}$ \\
\hline \multirow{2}{*}{ Disadvantages } & 1. Typically the link between money growth and inflation is subject to long and uncertain lags. \\
\hline & $\begin{array}{l}\text { 2. The demand for money may not be stable, there may be instability of velocity and the money } \\
\text { supply may not be controllable (Jha and Rath, 2003). This is especially true of broad monetary } \\
\text { targets such as M2 or M3 and less so of narrow money. }\end{array}$ \\
\hline
\end{tabular}

\footnotetext{
${ }^{8}$ Another intermediate target often mentioned in the literature is nominal income targeting. However this is both hard to target and poorly related to the ultimate aims of monetary policy.
} 
The literature mentions several advantages of IT (Bernanke and Mishkin, 1997), especially when compared to other nominal anchors. In contrast to exchange rate targeting but like monetary targeting, IT enables monetary policy to focus on domestic considerations and to respond to shocks to the domestic economy. ${ }^{9}$ It needs to be stated, however, that the goals of IT are defined almost exclusively in terms of ameliorating inflation shocks, not other goals that may be of concern. IT, like exchange targeting, has the advantage that the people easily understand it. Monetary targeting is less likely to be understood in a transparent manner. Further, since the central bank has an explicit numerical inflation target, the possibility of slipping into a time inconsistency trap is reduced.

A recent and growing body of literature has argued that IT provides a convenient mechanism for central banks to combine rules and discretion in pursuing monetary policy. Thus Svensson (1999) argues that IT is 'decision making under discretion' with central banks following a targeting rule which sets interest rates to reduce the deviation between conditional inflation forecast (the intermediate target of monetary policy) and the inflation target to zero over the target horizon. Bernanke and Mishkin (1997) and White (2004) have made similar arguments.

In the context of an emerging market economy such as India the problem of monetary management in general and inflation control, in particular, get compounded by low policy credibility. In this context Calvo and Mishkin (2003) argue that the emerging market economies remain vulnerable to weak institutional credibility and

\footnotetext{
${ }^{9}$ Another alleged advantage of an IT regime is that deviations from inflation targets are routinely allowed in response to supply shocks. The price index on which the official inflation targets are based is often defined to exclude or moderate the effects of 'supply shocks'; for example, the officially targeted price index may exclude some combination of food and energy prices, indirect tax changes, terms of trade shocks and the direct effects of interest rate changes on the index. Further, following (or in anticipation) of a supply shock, such as a rise in the value-added tax, the normal procedure is for the central bank to deviate from its planned policies as needed and then to explain the reasons for its action to the public.
} 
thus to sudden stops of capital inflows. This makes emerging markets prone to financial crises and it would be in their interest to adapt a rules-based monetary regime (like IT). In a similar vein Taylor (2002) argues that when rules-based policies are followed the anticipation effects of monetary policy are higher. Given their less developed financial markets such anticipatory effects are likely to be lower. Yet monetary policy could still have considerable effects through the movements of wages and property prices. With an IT regime in place this may be subject to lower shocks from the monetary regime and, hence, there is transmission channel argument for using the IT approach.

Persuaded by some of these arguments a number of developing countries have taken up IT. But India has not.

\section{The mechanics of Inflation Targeting}

The mode of working of a typical IT regime is as follows. The central bank is not committed to any particular instrument arrangement and therefore enjoys flexibility in setting the interest rate. Typically the central bank revises its inflation and output forecast at a frequency determined by that of monetary policy committee meetings using updated information. If the conditional inflation forecast is higher than the target, the central bank will raise the interest rate to minimize such deviation by the end of the targeting horizon, and vice versa. Households and firms then decide upon their consumption and investment plans. Blinder (1998) and Taylor (1993, 2002) argue that this is close to what many policymakers do in practice.

It has become common to compare ex post the actual setting of policy rates by central banks with what would have been predicted by the Taylor rule. The rule suggests that (short-term) interest rates should be changed in response to deviation of 
inflation from a target and an output gap. This is the so-called reaction function of central banks, literature on which is now blossoming (Svensson, 1999, Clarida et al., 1998, Mohanty and Klau, 2004).

Typically the central bank would set the federal fund rate (in the US) or the bank rate (in India) as a function of the output gap, current inflation and the difference between current inflation and its inflation target. The basic format of Taylor's rule is as follows:

$$
f^{*}{ }_{t}=\pi_{t}+r_{t}^{*}+0.5\left(\pi_{t}-\pi_{t}^{*}\right)+0.5 y_{t}
$$

where $\mathrm{f}_{\mathrm{t}}$ * is the bank rate, $\mathrm{y}_{\mathrm{t}}$ is the output gap expressed as a percentage of GDP and $r_{t} *$ is an equilibrium real interest rate. Taylor assumed that $r_{t} *$ and $\pi$ were both equal to 2 per cent and the weights on $\mathrm{y}_{\mathrm{t}}$ and $\left(\pi_{\mathrm{t}^{-}} \pi_{\mathrm{t}}{ }^{*}\right)$ were both set equal to 0.5 . In applying his rule to the US for the 1987-92 period Taylor found that the proposed rule described the actual performance of policy very well. In particular the addition of exchange rates or the level of money supply seemed to add little to the performance of (1).

Of course, IT is not applied mechanically. The IT rule does not simply focus on current inflation but on containing inflation as a medium-term goal. Hence central banks pay close attention to indicators that can predict future inflation accurately (Bernanke and Mishkin, 1997). This conclusion is backed by empirical evidence from a number of countries. ${ }^{10}$

An important consideration in using an IT regime anywhere is deciding the price index number to which the IT policy should respond. Typically the advice is to

\footnotetext{
${ }^{10}$ Thus Seyfried and Bremmer (2003) discover in the case of Australia that the Reserve Bank of Australia pays particular attention to inflationary pressures, as measured by the GDP gap. They find a relatively high degree of persistence and low speed of adjustment in the interest rate. This indicates that the cental bank is interested in interest smoothing in addition to inflation targeting. Similar comments apply to several other central banks in developed as well as in transition economies. For a lucid discussion of the many factors that are involved in actually running an inflation targeting monetary policy regime see Lomax (2005).
} 
include a CPI and, even better, a measure of core inflation that ignores excessively volatile prices such as those of energy products. ${ }^{11}$ A pertinent consideration here is whether IT should respond to asset price changes. There have been some significant episodes of asset price bubbles in the recent past. Typically these episodes involve fundamental factors bringing about an initial rise in the price of assets (e.g. commodities, stocks, real estate), which is then magnified through subsequent speculative activity followed by a sharp fall that occurs in response to the fact that fundamentals have remained unchanged. Should an IT program respond to such asset price bubbles?

Rather than confronting this question directly Bean (2003) analyses how asset prices should enter into a monetary policy framework, given an objective function that minimizes output gaps and deviation form inflation targets. He comes to the conclusion that the design of an optimal monetary policy regime would require a middle solution between completely ignoring asset prices and including asset prices regularly in the price index number to be used for inflation targeting. The former would imply that policymakers are completely ignoring the information content of asset prices whereas the latter would be inadvisable in a situation when say in response to rising asset prices in an otherwise sluggish economy the central bank hat to raise interest rates thus aggravating recessionary tendencies. Bean is of the opinion that one should include asset prices in an IT framework only to the extent that they influence inflationary expectations.

Central banks now operate in an environment of considerable uncertainty about the functioning of the economy as well as global capital flows. Hence it would

\footnotetext{
${ }^{11}$ The pursuit of an IT policy for India is further hamstrung by the fact that a single price index with widespread acceptability does not exist. There is a wholesale price index and at least two consumer price indices. Measures of core inflation for India are not computed officially. For an effort in this direction see Mohanty et al. (2000).
} 
be natural to assume that the conduct of monetary policy must be informed by examining a number of indicators and cannot rely on just one intermediate target — the rate of inflation. Even developed countries (such as New Zealand) with mature financial markets and practicing IT examine a number of indicators. In this process most central banks practice liquidity management, which broadly follows a two-step procedure of estimating market liquidity, autonomous of policy action, to initiate liquidity operations to steer monetary conditions. A key advantage of this framework is that it is possible to switch between quantitative targets and interest rate targets in response to the macroeconomic circumstances of the economy. Just as there are automatic stabilizers in the process of fiscal policy most central banks try to build in automatic stabilizers in the liquidity management framework. First, reserve requirements set on an average basis allow the financial system the leverage to adjust to temporary/seasonal liquidity shocks on its own account without central bank action. A second automatic stabilizer results from the central banks’ preference for encasing short-term interest rates in a corridor around some optimal rate than at a point target. It is evident that the transformation of monetary policy in the wake of financial sector reforms is far from complete.

\section{Has Inflation Targeting been a Success}

There is considerable debate about whether IT improves performance in regard to inflation and output. Thus whereas Ball and Sheridan (2003) argued that the adoption of IT does not lead to a systematic improvement in the growth-inflation tradeoff, $\mathrm{Hu}$ (2004) argues otherwise.

It is with this in mind that Fraga et al. (2003) concentrate exclusively on emerging market economies (India being one of them) and show that emerging 
market economies working within an IT framework have higher volatilities of output, inflation, interest rates and exchange rates than developed countries using IT. This is displayed in Table 5.

Table 5: Volatility and Average of Selected Variables for 1997:1-2002:2 (quarterly data)

\begin{tabular}{|c|c|c|c|c|c|c|}
\hline \multirow[b]{2}{*}{ Countries } & \multicolumn{4}{|c|}{ Volatility of basic variables } & \multicolumn{2}{|c|}{ Average } \\
\hline & Inflation & $\begin{array}{l}\text { Exchange } \\
\text { Rate* }^{*}\end{array}$ & GDP growth** & Interest rate & GDP growth & Inflation \\
\hline \multicolumn{7}{|c|}{ Developed Economies } \\
\hline Australia & 2.05 & 0.13 & 1.96 & 0.58 & 4.78 & 5.89 \\
\hline Canada & 0.83 & 0.04 & 1.30 & 1.14 & 3.57 & 1.96 \\
\hline Iceland & 2.45 & 0.15 & 3.13 & 3.02 & 4.17 & 4.05 \\
\hline New Zealand & 1.21 & 0.16 & 3.61 & 1.47 & 3.09 & 1.65 \\
\hline Norway & 0.77 & 0.10 & 2.25 & 1.46 & 2.66 & 2.44 \\
\hline Sweden & 1.11 & 0.12 & 2.41 & 0.44 & 2.58 & 1.24 \\
\hline Switzerland & 0.54 & 0.08 & 1.14 & 0.92 & 1.79 & 0.85 \\
\hline United Kingdom & 0.92 & 0.06 & 0.79 & 1.13 & 2.61 & 2.46 \\
\hline Average & 1.24 & 0.11 & 2.07 & 1.27 & 3.16 & 2.57 \\
\hline Median & 1.02 & 0.11 & 2.11 & 1.13 & 2.88 & 2.20 \\
\hline \multicolumn{7}{|c|}{ Emerging Market Economies } \\
\hline Brazil & 2.09 & 0.31 & 2.06 & 7.06 & 1.81 & 5.89 \\
\hline Chile & 1.30 & 0.17 & 3.25 & - & 3.11 & 3.88 \\
\hline Colombia & 5.43 & 0.25 & 3.38 & 10.02 & 0.81 & 12.51 \\
\hline Czech Republic & 3.46 & 0.09 & 2.73 & 5.81 & 1.18 & 5.31 \\
\hline Hungary & 4.09 & 0.16 & - & 1.13 & - & 11.21 \\
\hline |srael & 3.18 & 0.10 & 3.36 & 3.34 & 2.98 & 4.35 \\
\hline Mexico & 5.98 & 0.07 & 3.17 & 7.26 & 4.05 & 11.72 \\
\hline Peru & 3.04 & 0.11 & 3.45 & 5.50 & 2.11 & 3.89 \\
\hline Poland & 4.13 & 0.11 & 2.40 & 4.14 & 3.85 & 8.40 \\
\hline South Africa & 2.13 & 0.26 & 1.11 & 3.65 & 2.26 & 6.51 \\
\hline South Korea & 2.36 & 0.14 & 6.38 & 5.52 & 4.31 & 3.73 \\
\hline Thailand & 3.25 & 0.14 & 6.13 & 6.72 & 0.08 & 2.88 \\
\hline Average & 3.37 & 0.15 & 3.40 & 5.47 & 2.41 & 6.69 \\
\hline Median & 3.22 & 0.14 & 3.25 & 5.52 & 2.26 & 5.60 \\
\hline \multicolumn{7}{|c|}{$\begin{array}{l}\text { Notes: }{ }^{*} \text { refers to the coefficient of variation (standard deviation/mean) } \\
{ }^{* *} \text { growth rate measured comparing the current quarter to the same quarter of the previous year. }\end{array}$} \\
\hline \multicolumn{7}{|c|}{ Source: International Financial Statistics, IMF (quarterly data) } \\
\hline
\end{tabular}

In addition preparations for a switch to an IT regime requires considerable background work. The country should have sufficiently developed financial markets 
and global capital markets should have adequate confidence in these markets thus enabling the country to have a sufficiently flexible exchange rate regime. Further, all countries that have adopted IT have a high degree of central bank independence with considerable, if not total, freedom in setting monetary policy instruments and a minimal burden of financing government deficits. Further these central banks should be in the position to use short-term interest rates as the main operating instruments and rely on well-developed financial markets to alter longer-term rates and transmit the effects of those changes to aggregate demand and inflation. Further, inflation targets are announced on the basis of forecasted inflation insofar as they represent a promise to offset the foreseeable deviations of future inflation from the pre-specified targets over a period of one to two years. All countries using IT aim to enhance the credibility of the general macroeconomic policy. This is facilitated by mutual agreement between the monetary and fiscal authorities about inflation targets and the associated need for fiscal restraint. Further, in most countries IT has been introduced when the inflation rate was already low — below 10 per cent. Hence IT has contributed to building the credibility of the monetary mechanism and maintaining a low rate of inflation rather than bringing down inflation on its own.

\section{Recent Indian Experience with Nominal Targeting}

Indian monetary policy has never pursued a pure nominal targeting regime, opting for a combination of rules-based and discretionary measures with the rules-based target changing over time. Thus in the 1980s and early 1990s India opted for the nominal anchor of a nominal exchange rate peg, externally, and internally by monetary control. However, there is substantial evidence now that both these policy mechanisms have faltered. An inflexibly pegged exchange rate has proved to be 
unsustainable in the presence of strong capital flows ${ }^{12}$ whereas the instability of the money demand function as well as its supply (Jha and Rath, 2003) indicates that monetary targeting, by itself, is no longer a feasible option.

Empirical evidence suggests that in emerging market economies such as India central bank interest rates react more strongly to changes in the exchange rate rather than changes in the inflation rate or output gap (Mohanty and Klau, 2004). Hence, at this point in time, it does not seem that the standard tool to target inflation — short term interest rate — is going to be particularly useful. In section VIII I buttress this with estimates of a VAR model for India. It appears that even if the RBI wanted to it would be difficult for it to pursue a credible IT strategy.

Even assuming that IT does guarantee price stability does the attainment of such price stability guarantee the attainment of financial stability? In this context RBI (2004) notes that the 1990s — a decade of relative price stability- witnessed a number of episodes of financial instability indicating that price stability is not a sufficient condition for financial stability. Large movements in capital flows and exchange rates affect the conduct of monetary policy continually. Thus impacting on the traditional tradeoff between inflation and growth is the factor of financial instability. A number of authors (Bernanke and Gertler, 2001; Bernanke, 2003; Bean, 2003; and Filrado, 2004) have argued that irrespective of the fact that price stability may not imply financial stability in the short run, a policy focused exclusively on price stability is still desirable since there is no evidence that such a policy would endanger financial stability. There is little doubt that price stability and financial stability would reinforce

\footnotetext{
${ }^{12}$ However, there is evidence to suggest that India has been able to pursue real effective exchange rate (REER) targeting. As Joshi and Sanyal (2004) indicate the RBI has been targeting REER of the Indian rupee with regard to the currencies of five countries, U.S.A., Japan, UK, Germany and France, at the 1993-94 level. Patel and Srivastava (1997) note that such targeting has more than a transitory effect in the Indian context. Unlike in many Latin American countries REER targeting (even when requiring nominal devaluations) has not been particularly inflationary in India. However this benign relationship may break as reforms lead to greater capital mobility.
} 
each other in the long run but in the short run central banks in emerging market economies would often face tradeoffs between the two. In an economy with relative price stability the interest rate should not remain passive (as it would in an IT regime) if the economy faces a sudden capital outflow. Such situations are likely to be faced by central banks on a regular basis in many emerging market economies. Thus as RBI (2004) notes '(while) there is very little disagreement over the fact that price stability should remain a key objective of monetary policy, reservations persist ${ }^{13}$ about adopting it as the sole objective of monetary policy’ (pp. 56).

In the Indian case there is the further problem that the monetary authority faces a persistent fiscal overhang. Ultimately price stability and inflation expectations are dependent upon the fiscal regime in the economy. The central bank does not have the option of not supporting a high fiscal deficit. If fiscal policy is imprudent and the central bank does not help finance the deficit, the end result would still be inflationary as the public debt/GDP ratio would turn unsustainable in the medium term and the price level could at least partially be determined by the fiscal theory of the price level. Thus a rigid adherence to central bank independence may not be appropriate. ${ }^{14}$

Fiscal deficits are not only inflationary they also put pressure on real interest rates and crowd out private investment (Engen and Hubbard, 2004). There is a vicious cycle between inflation and budget deficits — high deficits cause higher inflation, which raise interest rates, which then raise the deficit itself by raising debt service payments, thus completing a vicious cycle. In addition, the higher inflation has the additional feedback effect of reducing the real value of tax collections.

\footnotetext{
${ }^{13}$ On this point see also Epstein (2004).

${ }^{14}$ Even in the context of Latin Amercian countries Jacome and Vazquez (2005) find no causal relationship between central bank independence and inflation, although the association between the two is strong.
} 
In the extant literature much emphasis has been placed on frameworks based on the clear mandates of central bank independence and fiscal responsibility legislation. On the one hand fiscal rules restrict unbridled government spending and this checks the excessive build-up of deficits and public debt, which imparts stability to the economy. On the other hand, fiscal rules may restrict the government's ability to take countercyclical policy measures and hence, contribute to increased business cycle volatility. Overall fiscal policy rules are likely to be effective if they are accompanied by strong commitments and increased transparency (Bayoumi and Eichengreen, 1995). Hence there is widespread consensus in favour of central bank independence backed by some form of fiscal discipline but with a clear emphasis on the former. Such clear-cut arrangements are an essential pre-requisite to contain inflation and stabilize inflationary expectations.

Although price stability, output growth, reduction of exchange rate volatility and financial stability are the goals of monetary policy in India none of these are under the direct control of the central bank. Monetary authorities set intermediate targets, which they can control but which are closely correlated and have a stable relationship with the ultimate goals of monetary policy. The choice of the intermediate targets is critical. A macro variable, if too narrow, such as base money, may be fully within the central bank purview but could be incapable of providing an effective means to pursue the ultimate objectives of monetary policy. On the other hand we can make the mistake of choosing a broad macro target such as nominal income, which, while being closely related to the ultimate objectives of monetary policy, may not be amenable to central bank control. However, in the Indian case there is substantial evidence now that not just the money demand but also the money multiplier has become more unstable with the onset of financial sector reforms in 
India (Jha and Rath, 2003). This argument could be extended to include other nominal targets as well and a purely rules-based monetary policy regime starts to appear unhelpful.

\section{Recent Developments in the Design of Monetary Policy in India}

With the progressive widening of fiscal deficits from the 1960s onwards, the burden of financing was borne by the RBI and the banking system. The support of the banking system to the Government’s borrowing program took the form of a progressive increase in the Statutory Liquidity Ratio (SLR). Although interest rates on government securities were steadily raised to enhance their attractiveness in the market it got increasingly difficult to get voluntary subscriptions even at high rates of interest. Thus the SLR was raised to 38.5 per cent by the early 1990s. The Cash Reserve Ratio (CRR) was increased from 3 per cent in the early 1970s to reach almost 25 per cent (if incremental reserve requirements are taken account of) by the early 1990s. Despite this liquidity growth remained excessively high during the 1970s and 1980s and later spilled over onto inflation. There are limits to the effectiveness of monetary policy in containing inflation in the face of expansionary fiscal policy. Not only is the Centre's fiscal deficit still substantial, but also the share of net bank credit to the Government in financing the fiscal deficit remains high (hovering around 10 per cent of GDP for much of the past decade).

A major development in the design of monetary policy in India was the constitution of the Sukhamoy Chakravarty Committee on Monetary Policy in 1985. The committee recommended that price stability emerge as the 'dominant' objective of monetary policy with concomitant commitment to fiscal discipline (RBI 2002, pp. 67). When the reforms process began in 1991 the ultimate mission for monetary 
policy was to emphasize inflation control. Price stability was seen to be critical to sustain the process of reforms (RBI 1993). In the latter half of the 1990s, as the economy slowed down, monetary policy pursued an accommodative stance with an explicit policy preference for a softer interest rate regime while continuing a constant vigil on the inflation front. In the RBI's view there are several constraints in pursuing a sole price stability objective.

(i) The recurrence of supply shocks limits the role of monetary policy in the inflation outcome. Structural factors and supply shocks from within and abroad make inflation in India depend on monetary as well as nonmonetary factors. McKibbibn and Singh (2003) formally demonstrate the inferiority of an IT regime in the context of India.

(ii) The persistence of fiscal dominance implies that debt management function get inextricably linked with the monetary management function.

(iii) The absence of fully integrated financial markets suggest that the interest rate transmission channel of policy is rather weak and yet to evolve fully. In particular the lags in the pass-through from the policy rate to bank lending rates constrain the adoption of inflation targeting.

(iv) The high frequency data requirements including those of a fully dependable inflation rate for targeting purposes are yet to be made. (RBI 2004).

The RBI formally adopted a multiple indicator approach in April 1998. Besides broad money which remains an information variable, a host of macroeconomic indicators including interest rates or rates of return in different markets (money, capital and government securities markets) along with such data as on currency, credit extended by banks and financial institutions, fiscal position, trade, capital flows, 
inflation rate, exchange rate, refinancing and transactions in foreign exchange available on high frequency basis are juxtaposed with output data for drawing policy perspectives in the process of monetary policy formulation.

The large list of indicators has been criticized as a 'check list' approach, which tends to water down the concept of a nominal anchor for monetary policy. At the same time it is very difficult to find a variable, which would be able to encapsulate the larger number of factors, which need to go into monetary policy making at this stage of transition from a relatively autarkic administered economy to a relatively open market-oriented economic system.

Short-term interest rates have emerged as instruments to signal the stance of monetary policy. The RBI uses a mix of policy instruments including changes in reserve requirements and standing facilities and open market (including repo) operations which affect the quantum of marginal liquidity and changes in policy rates, such as the Bank Rate and reverse repo/repo rates, which impact the price of liquidity. The RBI had originally conducted its monetary policy through a standard mix of open market operations and changes in the Bank Rate.

The liberalization of the Indian economy required a comprehensive recast of the operating procedures of monetary policy. The RBI had to shift from direct to indirect instruments of monetary policy in consonance with the increasing market orientation of the economy. Further, shifts in monetary policy transmission channel necessitated policy impulses which would travel through both quantity and rate channels and the episodes of volatility in foreign exchange markets emphasized the need for swift policy reactions balancing the domestic and external sources of monetization in order to maintain orderly conditions in the financial markets. Even within the set of indirect instruments the preference is for relatively more market-based instruments such as 
such as open market operations. Monetary authorities are increasingly required to take cognizance of not only domestic shocks but also external shocks. Given its objectives the RBI is required to monitor various segments of financial markets to ensure orderly conditions.

A more serious challenge to monetary policy comes from the capital account. A distinctive feature of capital flows is their greater volatility vis-à-vis trade flows. External borrowings of India are denominated in foreign currency. Large devaluations not only lead to inflation but can also cause serious currency mismatches with adverse effects on the balance sheets of borrowers (banks as well as corporates). The need for reserves as self-insurance emanates from the volatile nature of the capital flows. It also reflects weakness in the existing international financial architecture. Capital inflows can reverse quickly leaving the country exposed to a liquidity crisis. In this context the distinction between 'push' and 'pull' factors becomes important. While 'push' factors attribute capital flows to conditions in creditor countries, the 'pull' factors refer to conditions in debtor (recipient) countries. As a consequence India's ratio of net foreign assets to reserve money has grown from 11.9 per cent in 1990 to 44.5 per cent in 1996, 65.8 per cent in 2000 and 117.3 per cent in 2003.

\section{Reasons why India may not be ready for IT}

That transition economies such as India may not be ready for IT is the considered view not just of the RBI but also IMF economists. Thus Masson, Savatano and Sharma (1997) argue that economic structures in developing countries (including India) are incapable of supporting an IT regime in the short to medium runs. This is essentially because such countries do not satisfy a number of prerequisites for the successful implementation of inflation targeting. The authors consider these to be: 


\section{(a) Independence of the central bank}

This refers not just to operational efficiency but also to the policy space within which the central bank can operate. There are limits to the effectiveness of monetary policy in containing inflation in the face of expansionary fiscal policy. Not only is the Centre's fiscal deficit still substantial (the fiscal deficit of the central and state governments together has been in the excess of 10 per cent of GDP for several years now) but also the share of net bank credit to the Government in financing the fiscal deficit remains high. Domestic and financial markets should have enough depth to absorb the placement of public and private debt instruments; and the accumulation of public debt should be sustainable. In the Indian case while there is some evidence to suggest that the latter condition is satisfied (Jha and Sharma, 2004) the first is definitely not (Sharma, 2004). If these conditions are not all satisfied then the independence of monetary from fiscal policy is compromised — particularly at high rates of monetization of the deficit. The absence of fully integrated financial markets suggest that the interest rate transmission channel of policy is rather weak and yet to evolve fully. In particular the lags in the pass-through from the policy rate to bank lending rates constrain the adoption of inflation targeting.

In addition, the central government can, even in this age of financial liberalization, apply subtle pressure on the RBI to alter monetary policy. I give two instances of these. In the latter half of 2004 when inflation topped 8 per cent in India and real interest rates had become negative, the RBI wanted to raise the bank rate to lower inflation but could not, under government pressure. Similarly in early 2005 the Governor of the RBI publicly voiced concern over volatile FII inflows and suggested a fiscal approach to capping them. However, the Finance Minister almost immediately rebuffed him. 


\section{b. Refraining from using any other nominal anchor}

Another important requirement for the successful adoption of IT is that the authorities should desist from targeting any other nominal variable such as the exchange rate. As argued above, India needs to maintain a stable and competitive exchange rate to encourage exports. It is well known that even in developed economies, which have explicitly opted for it, IT is associated with a high degree of exchange rate flexibility. In view of their vulnerability to exchange rate crises developing countries such as India should be wary of excessive exchange rate flexibility. A high degree of exchange rate flexibility (and, by implication, volatility) will certainly not suit India’s economic growth prospects at this juncture.

In addition to the above the following reasons also make the adoption of IT difficult in India.

\section{c. Predominance of demand as opposed to supply shocks}

An implicit assumption behind IT that monetary policy has to respond primarily to demand side shocks. Balakrishna $(1991,1992)$ has emphasized the role of supply side factors in the context of structuralist models of inflation applied to India. ${ }^{15}$ The recurrence of supply shocks limits the role of monetary policy in the inflation outcome. Structural factors and supply shocks from within and abroad make inflation in India depend on monetary as well as non-monetary factors. If there is a negative supply shock output falls and inflation rises. If the central bank follows an IT policy it will raise interest rates to lower inflation. The resulting drop in aggregate will further aggravate the output drop. McKibbin and Singh (2003) demonstrate that because of the prevalence of supply shocks an IT regime is not suitable for India. If inflation rises because of a demand shock the pursuit of IT will stabilize both inflation and output.

\footnotetext{
${ }^{15}$ For a review of the literature on inflation in India see Callen and Chang (1999).
} 
However, if inflation rises because of an adverse supply shock the pursuit of IT will exacerbate the recessionary effect on output by reducing demand. Supply shocks are of considerable importance in transition countries such as India.

\section{d. Practical difficulties in the implementation of IT}

The high frequency data requirements including those of a fully dependable inflation rate for targeting purposes are yet to be made (RBI 2004). Further, there appears to be consensus that demand side factors alone cannot explain inflation in India (Callen and Chang, 1999), thus making the case for use of an IT program tenuous.

\section{Checking for Viability of IT in India}

A prerequisite for the RBI to pursue IT is that there should exist a stable and significant relationship between the measure of inflation to be controlled and shortterm interest rates. I test for this using monthly data over the period April 1992 to March 1998 from the RBI’s Handbook of Statistics on the Indian Economy. The variables used are as follows:

1. IIP: Index of Industrial Production $(1980-81=100)$

2. REER: Index of real effective exchange rate (36-country), 1985=100

3. Namon: Narrow Money

4. Cmrate: Call money rate

5. Xrate: Exchange rate of Indian rupee vis-a-vis US dollar (monthly averages)

6. CPI: Consumer Price Index for industrial workers $(1982=100)$

7. WPITR20: Trimmed WPI (Source Mohanty et al. 2000)

8. WPI: Wholesale Price Index (1993-94=100)

9. WPIADM: Wholesale Administered Price index (Source Mohanty et al. 2000) 
Monthly dummies were added to the time series and logs were taken of all variables except the call money rate. Augmented Dickey Fuller tests (not reported here to conserve space) indicated that all series are I(1).

To illustrate the bivariate relationships between the three candidate inflation measures and the monthly economic indicators, the P-values from bivariate Granger causality tests are presented in Table 6. Each entry in the table gives the P-values for the null hypothesis that the indicator does not cause the inflation measure - i.e., the probability of obtaining a sample, which is even less likely to conform to the null hypothesis of no Granger-causality than the sample at hand. Values smaller than 5 per cent are presented in bold. Three measures of inflation are used — the CPI, WPITR20 (defined below) and a measure of administered prices (mainly fuel prices). These Granger causality results are reported up to eight lags.

The WPITR20 measure of inflation is developed as follows. Assuming that the WPI is the headline measure of inflation, as is the case in India, the trimmed mean inflation index can be expressed by the following formula:

$$
\text { WPITR }_{\alpha}=\frac{1}{\left(1-2\left(\frac{\alpha}{100}\right)\right)} \sum_{i=k+l}^{n-1} w_{i} \pi_{i}
$$

where $\mathrm{WPITR}_{\alpha}$ is the trimmed WPI computed by ordering the component price change data $\pi_{\mathrm{I}}$ and their associated weights $\mathrm{w}_{\mathrm{i}}$ and removing the components on each tail of the distribution by $\alpha$ per cent. The number of components trimmed from the left and right tails of the distribution are $k$ and $l$ respectively. In the case of $\alpha=0$ the trimmed mean would equal the weighted mean whereas in the case of $\alpha=50$ it would equal the weighted median. The root mean square error (RMSE) for any level of trimming is defined by 
$R M S E_{\alpha}=\sqrt{\sum_{i=1}^{n}\left(p_{t}^{\alpha}-\pi_{t}\right)^{2} / n}$

where $\mathrm{p}_{\mathrm{t}}{ }^{\alpha}$ is the trimmed WPI with a trimming ratio of $\alpha$ per cent from each of the tails of the price distribution at time $t, \pi_{\mathrm{t}}$ is the 36-month centred moving average change in WPI at time $t$, and $n$ is the number of samples. Mohanty et al. (2000) conclude that this RMSE is minimized for $\alpha=20$. This is what we use for our measure of core inflation in India. Data on this variable is available in Mohanty et al. (2000).

The results of the Granger causality test indicate a weak relation between the short-term interest rate (call money rate) and the measures of inflation. In fact only WPITR20 seems to have a causal relation with the call money rate. On the other hand the links between the measures of inflation and IIP, narrow money, exchange rate and reer appear to be much stronger. Hence the results of the causality tests do not provide support for using interest rates as instruments in a policy of inflation targeting. 
Table 6: $P$ values from Bivariate Granger Causality Tests

\begin{tabular}{|c|c|c|c|c|c|}
\hline CPI & IIP & Exrate & Narmon & REER & Cmrate \\
\hline \multicolumn{6}{|l|}{ Lags } \\
\hline 1 & 0.22 & 0.67 & 0 & 0.64 & 0.35 \\
\hline 2 & 0.4 & 0.72 & 0 & 0.99 & 0.43 \\
\hline 3 & 0.69 & 0.87 & 0 & 0.61 & 0.93 \\
\hline 4 & 0.1 & 0.5 & 0 & 0.46 & 0.8 \\
\hline 5 & 0.01 & 0.25 & 0 & 0.36 & 0.55 \\
\hline 6 & 0 & 0.13 & 0 & 0.26 & 0.58 \\
\hline 7 & 0 & 0.12 & 0 & 0.12 & 0.69 \\
\hline 8 & 0 & 0.16 & 0 & 0.03 & 0.82 \\
\hline \multicolumn{6}{|l|}{ WPITR20 } \\
\hline \multicolumn{6}{|l|}{ Lags } \\
\hline 1 & 0.06 & 0 & 0.07 & 0.01 & 0.14 \\
\hline 2 & 0.01 & 0 & 0.01 & 0 & 0.09 \\
\hline 3 & 0 & 0 & 0 & 0 & 0 \\
\hline 4 & 0 & 0 & 0 & 0 & 0.04 \\
\hline 5 & 0 & 0 & 0 & 0 & 0.19 \\
\hline 6 & 0 & 0 & 0 & 0 & 0.2 \\
\hline 7 & 0 & 0 & 0 & 0 & 0.14 \\
\hline 8 & 0 & 0 & 0 & 0 & 0.26 \\
\hline \multicolumn{6}{|l|}{ WPIADM } \\
\hline \multicolumn{6}{|l|}{ Lags } \\
\hline 1 & 0 & 0.33 & 0.08 & 0.75 & 0.45 \\
\hline 2 & 0 & 0.09 & 0.01 & 0.56 & 0.23 \\
\hline 3 & 0 & 0.03 & 0 & 0.44 & 0.18 \\
\hline 4 & 0 & 0 & 0 & 0.2 & 0.97 \\
\hline 5 & 0 & 0 & 0 & 0.01 & 0.44 \\
\hline 6 & 0 & 0 & 0 & 0 & 0.41 \\
\hline 7 & 0 & 0 & 0 & 0 & 0.4 \\
\hline 8 & 0 & 0 & 0 & 0 & 0.12 \\
\hline
\end{tabular}

Figures in Bold significant at $5 \%$ level

CPI Consumer Price Index

WPITR Trimmed whoesale price index

WPIADM Price Index for the administered goods

IIP Index of Industrial Production

Narmon Narrow Money

Exrate Exchange Rate Rs/\$

Reer Real Effective Exchange Rate

Cmrate Call Money Rate

An important drawback of the crude Granger causality testing is that it

provides no information about whether the sign of the (dynamic) bivariate

relationship is correct from the point of view of economic theory. In particular, while 
bivariate analysis give a rough indication of statistical relationships between inflation itself and leading indicators of inflation, omitted variables bias could be distorting the estimates significantly. I ran a VAR of the variables in STATA. The program retained the variables: lcpi, liip, lnarmon, lreer, cmrate. The appendix reports complete results on the VAR whereas Table 7 reports on the Vector error Correction model, under the stipulation there are three cointegrating variables in the system. 
Table 7: Vector Error Correction Model from VAR Estimation

\begin{tabular}{|c|c|c|c|c|c|c|c|c|c|}
\hline $\begin{array}{l}\text { D_lcpi } \\
\text { _ce1 }\end{array}$ & Coef. & Std. Err. & $z$ & $P>|z|$ & $\begin{array}{l}\text { D_Inarmon } \\
\text { ce1 }\end{array}$ & Coef. & Std. Err. & $z$ & $P>|z|$ \\
\hline L1 & -0.07944 & 0.070814 & -1.12 & 0.262 & L1 & -0.7398 & 0.198593 & -3.73 & 0 \\
\hline _ce2 & & & & & _ce2 & & & & \\
\hline L1 & 0.023994 & 0.021023 & 1.14 & 0.254 & L1 & -0.12046 & 0.058957 & -2.04 & 0.041 \\
\hline _ce3 & & & & & _ce3 & & & & \\
\hline L1 & 0.132008 & 0.071089 & 1.86 & 0.063 & L1 & 0.140916 & 0.199365 & 0.71 & 0.48 \\
\hline Icpi & & & & & Iсpi & & & & \\
\hline LD & 0.131275 & 0.181922 & 0.72 & 0.471 & LD & -0.18655 & 0.510191 & -0.37 & 0.715 \\
\hline L2D & -0.23919 & 0.169483 & -1.41 & 0.158 & L2D & 0.719971 & 0.475307 & 1.51 & 0.13 \\
\hline L3D & -0.00169 & 0.215543 & -0.01 & 0.994 & L3D & 1.506578 & 0.60448 & 2.49 & 0.013 \\
\hline L4D & -0.05345 & 0.218963 & -0.24 & 0.807 & L4D & 1.047828 & 0.614073 & 1.71 & 0.088 \\
\hline L5D & -0.34028 & 0.186329 & -1.83 & 0.068 & L5D & -0.04321 & 0.522552 & -0.08 & 0.934 \\
\hline L6D & -0.44903 & 0.220185 & -2.04 & 0.041 & L6D & -0.36949 & 0.617499 & -0.6 & 0.55 \\
\hline L7D & -0.40205 & 0.200613 & -2 & 0.045 & L7D & -0.51832 & 0.56261 & -0.92 & 0.357 \\
\hline Inarmon & & & & & Inarmon & & & & \\
\hline LD & -0.02688 & 0.064869 & -0.41 & 0.679 & LD & -0.75277 & 0.181923 & -4.14 & 0 \\
\hline L2D & -0.16421 & 0.075696 & -2.17 & 0.03 & L2D & -0.62109 & 0.212286 & -2.93 & 0.003 \\
\hline L3D & -0.03529 & 0.072121 & -0.49 & 0.625 & L3D & -0.65593 & 0.202259 & -3.24 & 0.001 \\
\hline L4D & 0.035828 & 0.060855 & 0.59 & 0.556 & L4D & -0.52284 & 0.170665 & -3.06 & 0.002 \\
\hline L5D & -0.13562 & 0.058738 & -2.31 & 0.021 & L5D & 0.020943 & 0.164727 & 0.13 & 0.899 \\
\hline L6D & -0.1029 & 0.064414 & -1.6 & 0.11 & L6D & 0.123258 & 0.180645 & 0.68 & 0.495 \\
\hline L7D & 0.057869 & 0.064654 & 0.9 & 0.371 & L7D & -0.25163 & 0.18132 & -1.39 & 0.165 \\
\hline Ireer & & & & & Ireer & & & & \\
\hline LD & -0.27617 & 0.073794 & -3.74 & 0 & LD & -0.26306 & 0.206952 & -1.27 & 0.204 \\
\hline L2D & -0.3703 & 0.092663 & -4 & 0 & L2D & -0.37759 & 0.259871 & -1.45 & 0.146 \\
\hline L3D & -0.20022 & 0.08892 & -2.25 & 0.024 & L3D & -0.48248 & 0.249372 & -1.93 & 0.053 \\
\hline L4D & -0.27274 & 0.073683 & -3.7 & 0 & L4D & -0.55818 & 0.20664 & -2.7 & 0.007 \\
\hline L5D & -0.21478 & 0.080797 & -2.66 & 0.008 & L5D & -0.40356 & 0.226592 & -1.78 & 0.075 \\
\hline L6D & -0.21545 & 0.071716 & -3 & 0.003 & L6D & -0.4324 & 0.201124 & -2.15 & 0.032 \\
\hline $\begin{array}{l}\text { L7D } \\
\text { cmrate }\end{array}$ & -0.1278 & 0.070095 & -1.82 & 0.068 & $\begin{array}{l}\text { L7D } \\
\text { cmrate }\end{array}$ & -0.4683 & 0.196579 & -2.38 & 0.017 \\
\hline LD & -0.00026 & 0.000579 & -0.45 & 0.655 & LD & 0.005749 & 0.001624 & 3.54 & 0 \\
\hline L2D & -0.00038 & 0.000604 & -0.64 & 0.525 & L2D & 0.00444 & 0.001695 & 2.62 & 0.009 \\
\hline L3D & -0.00094 & 0.00053 & -1.77 & 0.076 & L3D & 0.002242 & 0.001487 & 1.51 & 0.132 \\
\hline L4D & -0.00141 & 0.000513 & -2.75 & 0.006 & L4D & 0.001989 & 0.001438 & 1.38 & 0.167 \\
\hline L5D & -0.00117 & 0.000452 & -2.58 & 0.01 & L5D & 0.000425 & 0.001268 & 0.34 & 0.737 \\
\hline L6D & -0.00061 & 0.00032 & -1.91 & 0.056 & L6D & $1.42 \mathrm{E}-05$ & 0.000897 & 0.02 & 0.987 \\
\hline L7D & -0.00026 & 0.000223 & -1.17 & 0.242 & L7D & 0.00081 & 0.000626 & 1.29 & 0.196 \\
\hline liip & & & & & liip & & & & \\
\hline LD & -0.04796 & 0.10167 & -0.47 & 0.637 & LD & -0.8081 & 0.285128 & -2.83 & 0.005 \\
\hline L2D & -0.02251 & 0.092856 & -0.24 & 0.808 & L2D & -0.50525 & 0.260411 & -1.94 & 0.052 \\
\hline L3D & 0.001402 & 0.080376 & 0.02 & 0.986 & L3D & -0.1761 & 0.22541 & -0.78 & 0.435 \\
\hline L4D & 0.00135 & 0.066451 & 0.02 & 0.984 & L4D & 0.102729 & 0.186358 & 0.55 & 0.581 \\
\hline L5D & -0.01413 & 0.058448 & -0.24 & 0.809 & L5D & 0.183835 & 0.163915 & 1.12 & 0.262 \\
\hline L6D & 0.014915 & 0.048856 & 0.31 & 0.76 & L6D & 0.086086 & 0.137014 & 0.63 & 0.53 \\
\hline L7D & 0.003105 & 0.027414 & 0.11 & 0.91 & L7D & 0.003843 & 0.076881 & 0.05 & 0.96 \\
\hline _cons & 0.012931 & 0.003442 & 3.76 & 0 & _cons & 0.009592 & 0.009653 & 0.99 & 0.32 \\
\hline
\end{tabular}


Table 7: Vector Error Correction Model from VAR Estimation (cont'd)

\begin{tabular}{|c|c|c|c|c|c|c|c|c|c|}
\hline $\begin{array}{l}\text { D_Ireer } \\
\text { _ce1 }\end{array}$ & Coef. & Std. Err. & $z$ & $P>|z|$ & $\begin{array}{l}\text { D_cmrate } \\
\text { ce } 1\end{array}$ & Coef. & Std. Err. & $z$ & $P>|z|$ \\
\hline $\begin{array}{l}\text { L1 } \\
\text { _ce2 }\end{array}$ & 0.23669 & 0.215595 & 1.1 & 0.272 & $\begin{array}{l}\text { L1 } \\
\text { _ce2 }\end{array}$ & -9.2662 & 57.82143 & -0.16 & 0.873 \\
\hline $\begin{array}{l}\text { L1 } \\
\text { _ce3 }\end{array}$ & -0.04971 & 0.064005 & -0.78 & 0.437 & $\begin{array}{l}\text { L1 } \\
\text { _ce3 }\end{array}$ & 25.56354 & 17.16572 & 1.49 & 0.136 \\
\hline $\begin{array}{l}\text { L1 } \\
\text { Icpi }\end{array}$ & -0.74058 & 0.216432 & -3.42 & 0.001 & $\begin{array}{l}\text { L1 } \\
\text { Icpi }\end{array}$ & 76.52269 & 58.04598 & 1.32 & 0.187 \\
\hline LD & 0.126411 & 0.553869 & 0.23 & 0.819 & LD & 91.91419 & 148.5447 & 0.62 & 0.536 \\
\hline L2D & -0.40329 & 0.515999 & -0.78 & 0.434 & L2D & -163.033 & 138.388 & -1.18 & 0.239 \\
\hline L3D & 0.164285 & 0.65623 & 0.25 & 0.802 & L3D & -180.547 & 175.9973 & -1.03 & 0.305 \\
\hline L4D & -0.38158 & 0.666645 & -0.57 & 0.567 & $L 4 D$ & 149.13 & 178.7906 & 0.83 & 0.404 \\
\hline L5D & -1.45388 & 0.567289 & -2.56 & 0.01 & L5D & -67.6367 & 152.1437 & -0.44 & 0.657 \\
\hline L6D & -0.08419 & 0.670364 & -0.13 & 0.9 & L6D & -18.56 & 179.7879 & -0.1 & 0.918 \\
\hline L7D & -1.08 & 0.610776 & -1.77 & 0.077 & L7D & 91.90868 & 163.8068 & 0.56 & 0.575 \\
\hline Inarmon & & & & & Inarmon & & & & \\
\hline LD & -0.35526 & 0.197497 & -1.8 & 0.072 & LD & -95.0976 & 52.9677 & -1.8 & 0.073 \\
\hline L2D & 0.031007 & 0.230461 & 0.13 & 0.893 & L2D & -68.2513 & 61.80825 & -1.1 & 0.269 \\
\hline L3D & 0.036477 & 0.219575 & 0.17 & 0.868 & L3D & 4.176049 & 58.8887 & 0.07 & 0.943 \\
\hline L4D & 0.067441 & 0.185276 & 0.36 & 0.716 & L4D & -77.564 & 49.68986 & -1.56 & 0.119 \\
\hline L5D & 0.170845 & 0.17883 & 0.96 & 0.339 & L5D & -100.689 & 47.96118 & -2.1 & 0.036 \\
\hline L6D & 0.256766 & 0.19611 & 1.31 & 0.19 & L6D & -12.5069 & 52.59573 & -0.24 & 0.812 \\
\hline L7D & 0.039763 & 0.196843 & 0.2 & 0.84 & L7D & 21.21489 & 52.79226 & 0.4 & 0.688 \\
\hline Ireer & & & & & Ireer & & & & \\
\hline LD & 0.190545 & 0.224669 & 0.85 & 0.396 & LD & -208.699 & 60.25501 & -3.46 & 0.001 \\
\hline L2D & 0.262241 & 0.282119 & 0.93 & 0.353 & L2D & -120.102 & 75.66264 & -1.59 & 0.112 \\
\hline L3D & -0.02626 & 0.270721 & -0.1 & 0.923 & L3D & -16.066 & 72.60589 & -0.22 & 0.825 \\
\hline L4D & -0.05946 & 0.224331 & -0.27 & 0.791 & L4D & -117.275 & 60.16426 & -1.95 & 0.051 \\
\hline L5D & -0.27537 & 0.245991 & -1.12 & 0.263 & L5D & -17.1516 & 65.97329 & -0.26 & 0.795 \\
\hline L6D & 0.023921 & 0.218342 & 0.11 & 0.913 & L6D & -17.2904 & 58.55819 & -0.3 & 0.768 \\
\hline $\begin{array}{l}\text { L7D } \\
\text { cmrate }\end{array}$ & 0.121808 & 0.213409 & 0.57 & 0.568 & $\begin{array}{l}\text { L7D } \\
\text { cmrate }\end{array}$ & -13.6142 & 57.23499 & -0.24 & 0.812 \\
\hline LD & 0.003935 & 0.001763 & 2.23 & 0.026 & LD & -0.68795 & 0.472923 & -1.45 & 0.146 \\
\hline L2D & 0.002514 & 0.00184 & 1.37 & 0.172 & L2D & -0.45325 & 0.493473 & -0.92 & 0.358 \\
\hline L3D & 0.00029 & 0.001615 & 0.18 & 0.858 & L3D & -0.77772 & 0.433042 & -1.8 & 0.073 \\
\hline L4D & $-2.98 \mathrm{E}-06$ & 0.001561 & 0 & 0.998 & L4D & -0.41319 & 0.418531 & -0.99 & 0.324 \\
\hline L5D & 0.000851 & 0.001376 & 0.62 & 0.536 & L5D & -0.06012 & 0.369058 & -0.16 & 0.871 \\
\hline L6D & 0.000101 & 0.000974 & 0.1 & 0.917 & L6D & -0.11483 & 0.261236 & -0.44 & 0.66 \\
\hline L7D & 0.000975 & 0.000679 & 1.43 & 0.151 & L7D & 0.17633 & 0.182181 & 0.97 & 0.333 \\
\hline liip & & & & & liip & & & & \\
\hline LD & 0.510806 & 0.309539 & 1.65 & 0.099 & LD & 9.845296 & 83.01653 & 0.12 & 0.906 \\
\hline L2D & 0.457648 & 0.282705 & 1.62 & 0.105 & L2D & 28.21744 & 75.82004 & 0.37 & 0.71 \\
\hline L3D & 0.470819 & 0.244708 & 1.92 & 0.054 & L3D & 9.145638 & 65.62938 & 0.14 & 0.889 \\
\hline L4D & 0.477246 & 0.202312 & 2.36 & 0.018 & L4D & 1.771472 & 54.25899 & 0.03 & 0.974 \\
\hline L5D & 0.438266 & 0.177948 & 2.46 & 0.014 & L5D & -0.14672 & 47.7246 & 0 & 0.998 \\
\hline L6D & 0.273063 & 0.148744 & 1.84 & 0.066 & L6D & 23.42168 & 39.89235 & 0.59 & 0.557 \\
\hline L7D & 0.038602 & 0.083463 & 0.46 & 0.644 & L7D & 0.188936 & 22.38441 & 0.01 & 0.993 \\
\hline _cons & -0.01987 & 0.010479 & -1.9 & 0.058 & _cons & -0.0002 & 2.810493 & 0 & 1 \\
\hline
\end{tabular}




\begin{tabular}{|c|c|c|c|c|}
\hline $\begin{array}{l}\text { D_liip } \\
\text { _ce1 }\end{array}$ & Coef. & Std. Err. & $z$ & $P>|z|$ \\
\hline $\begin{array}{l}\text { L1 } \\
\text { _ce2 }\end{array}$ & 0.853878 & 0.430052 & 1.99 & 0.047 \\
\hline $\begin{array}{l}\text { L1 } \\
\text { _ce3 }\end{array}$ & 0.402199 & 0.127672 & 3.15 & 0.002 \\
\hline $\begin{array}{l}\text { L1 } \\
\text { Icpi }\end{array}$ & -0.15359 & 0.431722 & -0.36 & 0.722 \\
\hline LD & -1.21458 & 1.104815 & -1.1 & 0.272 \\
\hline L2D & -3.10089 & 1.029274 & -3.01 & 0.003 \\
\hline L3D & -1.12249 & 1.308996 & -0.86 & 0.391 \\
\hline L4D & 2.452112 & 1.329771 & 1.84 & 0.065 \\
\hline L5D & -0.25746 & 1.131583 & -0.23 & 0.82 \\
\hline L6D & -0.96154 & 1.337189 & -0.72 & 0.472 \\
\hline $\begin{array}{l}\text { L7D } \\
\text { Inarmo }\end{array}$ & -3.2064 & 1.218328 & -2.63 & 0.008 \\
\hline LD & -1.17364 & 0.393952 & -2.98 & 0.003 \\
\hline L2D & -0.75912 & 0.459705 & -1.65 & 0.099 \\
\hline L3D & -1.61192 & 0.43799 & -3.68 & 0 \\
\hline L4D & -0.23846 & 0.369573 & -0.65 & 0.519 \\
\hline L5D & -0.42517 & 0.356716 & -1.19 & 0.233 \\
\hline L6D & 0.068239 & 0.391186 & 0.17 & 0.862 \\
\hline $\begin{array}{l}\text { L7D } \\
\text { Ireer }\end{array}$ & -1.19182 & 0.392647 & -3.04 & 0.002 \\
\hline LD & -0.42598 & 0.448152 & -0.95 & 0.342 \\
\hline L2D & -0.61895 & 0.562748 & -1.1 & 0.271 \\
\hline L3D & -1.31204 & 0.540013 & -2.43 & 0.015 \\
\hline L4D & -0.22143 & 0.447477 & -0.49 & 0.621 \\
\hline L5D & -0.90564 & 0.490682 & -1.85 & 0.065 \\
\hline L6D & -1.02694 & 0.435532 & -2.36 & 0.018 \\
\hline $\begin{array}{l}\text { L7D } \\
\text { cmrate }\end{array}$ & -0.80851 & 0.425691 & -1.9 & 0.058 \\
\hline LD & 0.001816 & 0.003517 & 0.52 & 0.606 \\
\hline L2D & 0.00086 & 0.00367 & 0.23 & 0.815 \\
\hline L3D & -0.00173 & 0.003221 & -0.54 & 0.591 \\
\hline L4D & -0.00314 & 0.003113 & -1.01 & 0.313 \\
\hline L5D & -0.00522 & 0.002745 & -1.9 & 0.057 \\
\hline L6D & -0.00404 & 0.001943 & -2.08 & 0.038 \\
\hline $\begin{array}{l}\text { L7D } \\
\text { liip }\end{array}$ & 0.001187 & 0.001355 & 0.88 & 0.381 \\
\hline LD & 0.769114 & 0.617443 & 1.25 & 0.213 \\
\hline L2D & 0.880477 & 0.563919 & 1.56 & 0.118 \\
\hline L3D & 1.152687 & 0.488125 & 2.36 & 0.018 \\
\hline L4D & 0.94987 & 0.403556 & 2.35 & 0.019 \\
\hline L5D & 1.019589 & 0.354956 & 2.87 & 0.004 \\
\hline L6D & 0.878757 & 0.296703 & 2.96 & 0.003 \\
\hline L7D & 0.511007 & 0.166486 & 3.07 & 0.002 \\
\hline _cons & 0.012779 & 0.020903 & 0.61 & 0.541 \\
\hline
\end{tabular}


Figure 1 shows that the confidence band for the impulse response function of cmrate on lcpi is very wide, hence adding to our agnosticism about the efficacy of inflation targeting in India.

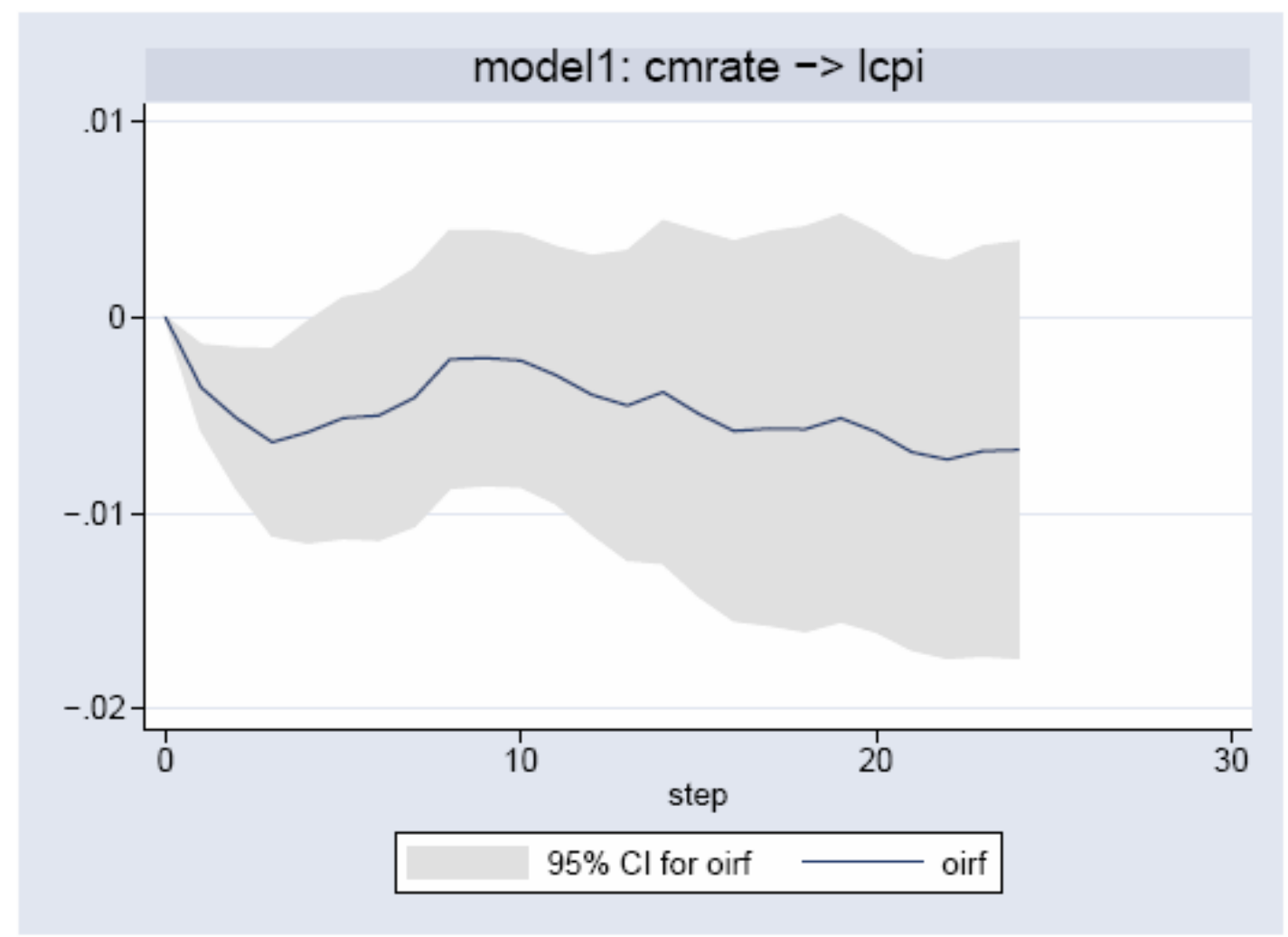

Figure 1

As is evident the ECM for lcpi is not significantly responsive to any of the error correction terms. Hence it appears that inflation targeting may be difficult to pursue in the Indian context.

\section{$\underline{\text { IX. Conclusions }}$}

This paper has argued that the primary objective of Indian monetary policy, at least in the medium term, has to be the attainment of higher economic growth. Further, since India has high inflation aversion, this objective does not conflict with that of shortterm stabilization. 
The design of monetary policy in India is circumscribed by the fact that the liberalization of financial markets is far from complete (so that the interest rate transmission channel is incomplete). Further the banking system has strong monopoly elements and the government owns overwhelming stake in the banking sectors (Sharma 2004). Further, as the financial sector liberalizes some major government owned mutual fund operations have had to be bailed out. The development of such continent liabilities along with the already high fiscal deficit exacerbates monetary policy difficulties in the Indian context and there does not appear to be any respite in sight.

Monetary policy in India has to be conducted against this background. This paper has argued that the multi-objective formulation pursued by the RBI has merit. This paper has argued that such monetary policy should be pursued to maintain stable interest and inflation rates and a slightly undervalued currency in order to engineer higher export led growth. This policy has led to the emergence of substantial capital inflows with attendant large build-up of reserves and necessitated considerable sterilization operations.

This accumulation of reserve has now emerged as a significant problem necessitating the development of a policy towards it. It continuance at the current pace seems unsustainable if for no other reason then the fact that accumulation of increasingly large reserves commits wealth to low yielding assets. At the current point in time two policy packages to address this issue have been discussed in policy circles. The first such package is geared towards fiscal correction and monetary expansion. Both these policy measures would lead to low inflation rates and reduced inflows of foreign capital and, therefore, lower accumulation of reserves at given rates of sterilization. A second policy measure is heavily weighted towards real exchange 
rate appreciation and would thus involve relatively larger current account deficits. Real appreciation, in turn, could be secured by nominal appreciation or by permitting higher inflation. Policy packages that use import liberalisation would, like real appreciation, permit higher absorption via higher current account deficits but without penalising exports. The optimal package for India is a judicious combination of these two broad sets of policies with greater emphasis on the first measure, i.e., the policy package should be biased towards fiscal consolidation and import liberalisation, rather than real exchange rate appreciation via nominal appreciation or inflation.

Since rapid export growth is important, it makes sense to err on the side of undervaluation of the exchange rate because growth of export demand is related to the level of the real exchange rate. An undervalued exchange rate enables a country to capture a larger share of world markets. (If world markets are growing at $x$ per cent, then the country's exports can grow faster than $x$ per cent during an adjustment period which can be quite long.) Growing exports, in turn, raise the incentive to invest. The propensity to save also rises in response to the increased profitability of exportoriented investment. Moreover, an undervalued exchange rate is likely to boost saving by raising the share of profits in national income. This argument should not be read as implying that unlimited real depreciation is feasible or desirable. All that is being argued is that there should be a bias towards mild undervaluation because it can play a supportive role to complementary outward-oriented trade policies in generating a virtuous circle of higher saving, investment, and growth. As the economy continues to grow at high rates import demand would grow concomitantly and getting a current account surplus is not inevitable.

Clearly India has been conducting some form of real exchange rate targeting. This has inevitably led to a sharp rise in foreign exchange reserves. Has this led to a 
drop in the potential rate of growth of the economy? Lal, Bery and Pant (2003) indicate that that India's growth rate in the 1990s could have been up to 2.7 per cent per annum higher if the foreign exchange inflows during the decade had been fully absorbed. However, as Joshi and Sanyal (2004) show this is a flawed argument. The Joshi and Sanyal argument proceeds as follows. If net foreign inflows had been absorbed domestic spending (and not foreign exchange reserves) would have risen. Reserves as a proportion of GDP rose over the 1990s by an average of about 1.2 per cent per annum. If the entire increase in reserves had been absorbed into investment each year, the ratio of investment to GDP averaged over the decade would thus have been 1.2 per cent higher than it actually was. The incremental net capital output ratio (ICOR) in the nineteen-nineties was 2.8. This implies, assuming a constant ICOR, that the increase in India's growth rate of GDP would have been $1.2 / 2.8=0.4$ per cent per annum (approx.) over the decade, a far cry from the Lal et al. (2003) estimate of 2.7 per cent. India's actual growth rate in the nineteen-nineties was 5.8 per cent. In line with the Joshi-Sanyal argument this could have been, at the most, 6.2 per cent. However, these are all optimistic assumptions and disregard the very low level of reserves in the base year, 1991. If these are taken into account the growth sacrifice was not very high, indeed there could have been a gain in growth as a result of this policy. The reasons are as follows. First, the ICOR need not have stayed constant (in line with the assumption of diminishing returns to capital) — hence the growth sacrifice would have been lower. Second, there is little reason to believe that the entire reserve accumulation would have been absorbed in investment, irrespective of the exchange rate regime in place. Some of it would have spilled over into higher consumption, thus reducing the growth rate. Further, as is well known, the level of foreign exchange reserves in India was inadequate in 1991. Building up of foreign 
reserves from that low base was necessary. Without the cushion of adequate reserves, the shelter of capital controls and the reassurance they provided to the authorities and the market, the exchange rate could have spun out of control and caused severe damage to companies and the financial sector.

The pursuit of IT would require India to pursue a clean float. This can enable the country to do without lage reserves. But the price to be paid is the possibility of a highly unstable or inappropriate exchange rate. India's policymakers were wise to reject this regime and opt for managed floating plus selective controls on capital flows. However, reserves are now at a very comfortable level but are continuing to rise at a rapid pace. The question of whether and how to absorb foreign inflows is far more pertinent now than it was in the 1990s.

Clearly sterilisation has outlived its usefulness. Some sterilised reserve accumulation can continue to maintain the present ratio of reserves to GDP. Further increases in the ratio should be avoided except as a purely short-term response to manifestly short-term inflows. The policies espoused here have the advantage that in addition to promoting balance of payments adjustment, they are desirable independently of the balance of payments, and of the 'temporary' or 'permanent' character of the inflows. Naturally, due to political and other constraints, these policies can only be pursued at a moderate pace. If there is continued acceleration of inflows, despite the adoption of the suggested strategy, the government should consider tightening capital inflow controls (e.g. by a Chilean-style tax) so that the strategy is not derailed. The appendix to this paper underscores the importance of capital controls in ensuring that the Indian economy did not go through a crisis in the late 1990s although its fundamentals were no better than those of many of the countries that did suffer such a crisis. 
It is not being suggested that India should resist an exchange rate appreciation indefinitely. Once India has grown at high rates (in excess of 8 per cent) for more than two decades so that real incomes have gone up substantially and unemployment and poverty have dropped sharply India could contemplate adopting an IT regime accompanied by floating exchange rates and capital account convertibility. At the present point in time this policy should certainly be eschewed. 


\section{References}

Balakrishna, P. (1991) Pricing and Inflation in India, Delhi: Oxford University Press.

Balakrishna, P. (1992) 'Industrial Price Behaviour in India: An Error-Correction Model’, Journal of Development Economics, vol. 37, no. 3, pp. 309-326.

Ball, L. and N. Sheridan (2003) ‘Does Inflation Targeting Matter?’, NBER Working Paper, no. 9577.

Barro, R. and D. Gordon (1983) 'A Positive Theory of Monetary Policy in a Natural Rate Model', Journal of Political Economy, vol. 91, no.4, pp. 589-610.

Bayoumi, T. and B. Eichengreen (1995) 'Restraining Yourself: The Implications of Fiscal Rules for Economic Stabilization', IMF Staff Papers, No. 42, pp. 32-48.

Bean, C. (2003) 'Asset Prices, Financial Imbalances and Monetary Policy: Are Inflation Targets Enough?', BIS Working Paper, No. 140.

Bernanke, B. (2003) ‘Constrained Discretion and Monetary Policy’, BIS Review, vol. 5.

Bernanke, B. and M. Gertler (2001) 'Should Central Banks Respond to Movements in Asset Prices?', American Economic Review, vol. 91, no. 2, pp. 253-257.

Bernanke, B. and F. Mishkin (1997) 'Inflation Targeting: A New framework for Monetary Policy?', Journal of Economic Perspectives, vol. 11, no. 2, pp. 97-116.

Blinder, A. (1998) Central Bank in Theory and Practice, Cambridge, MA.: MIT Press.

Callen, T. and D. Chang (1999) 'Modeling and Forecasting Inflation in India', IMF Working Paper WP/99/119, Washington, D.C.

Calvo, G. and F. Mishkin (2003) 'The Mirage of Exchange Rate Regimes for Emerging Market Countries 'Journal of Economic Perspectives, vol. 17, no. 4, pp. 99-118

Clarida, R., Gali, J. and M. Gertler (1998) 'Monetary Policy Rules in Practice: Some International Evidence', European Economic Review, vol. 42, no. 4, pp. 1033-1067.

Dollar, D. and A. Kraay (2001) 'Growth is Good for the Poor’, World Bank Policy Research Paper.

Engen, E. and R. Hubbard (2004) 'Federal Governments and Interest Rates', NBER Working Paper, no. 1068.

Epstein, G. (2000) Myth, Mendacity and Mischief in the Theory and Practice of Central Banking, available at: www.umass.edu/peri

Filrado, A. (2004) 'Monetary Price and Asset Price Bubbles: Calibrating the Monetary Policy Tradeoffs', BIS Working Paper, no. 155.

Fraga, A., Goldfajin, I. and A. Minella (2003) ‘Inflation Targeting in Emerging Market Economies’, NBER Working Paper 10019.

Hu, Y. (2004) 'Empirical Investigations of Inflation Targeting', Institute of International Economics, mimeo.

Jacome, L. and F. Vazquez (2005) 'Any Link between central bank independence and Inflation? Evidence from Latin America and the Caribbean', IMF Working Paper No. WP/05/75.

Jha, R. (2004) 'Reducing Poverty and Inequality in India: Has Liberalization Helped?', in A. Cornia (ed.) Inequality, Growth and Poverty in an Era of Liberalization and Globalization, Oxford: Oxford University Press.

Jha, R. (2005) 'The Political Economy of Recent Economic Growth in India', in R. Jha (ed.) Economic Growth, Economic Performance and Welfare in South Asia, Houndmills: Palgrave Macmillan.

Jha, R. and D. Rath (2003) 'On the Endogeneity of the Money Multiplier in India', in R. Jha (ed.) Indian Economic Reforms, Houndmills: Palgrave Macmillan. 
Jha, R. and A. Sharma (2004) 'Structural Breaks, Unit Roots, and Cointegration: A further test of the sustainability of the indian fiscal deficit’, Public Finance Review, vol. 32, no. 2, pp. 196-219.

Joshi, V.and S. Sanyal (2004) ‘Foreign Inflows and Macroeconomic Policy in India’, Mimeo Oxford University.

Kelkar, V. (2004) 'India on the Growth Turnpike’, Narayanan Oration, Australia South Asia Research Centre, Australian National University.

Kydland, F. and E. Prescott (1977) 'Rules Rather Than Discretion: The Inconsistency of Optimal Plans', Journal of Political Economy, vol. 87, no. 2, pp. 473-92.

Lal, D., Bery, S. and D. Pant (2003) 'The Real Exchange Rate, Fiscal Deficits and Capital Flows India: 1981-2000’, Economic and Political Weekly, XXXVIII (47), 4965-76.

Lomax, R. (2005) 'Inflation Targeting in Practice - Models, Forecasts and Hunches', Speech by the Deputy Governor of the Bank of England to the $59^{\text {th }}$ Atlantic Economic Conference, 12 March.

Masson, P., Savastano, M. and S. Sharma (1997) 'The Scope for Inflation Targeting in Developing Countries’, IMF Working Paper, 97/130.

McKibbin, W. and K. Singh (2003) 'Issues in the Choice of a Monetary Regime for India', in R. Jha (ed.) Indian Economic Reforms, Houndmills: Palgrave Macmillan.

Mishkin, F. (1998) 'International Experiences with different international monetary policy regimes', Seminar Paper no. 648, Institute for International Economics, Stockholm University.

Mohanty, D., Rath, D. and M. Ramaiah (2000) 'Measures of Core Inflation for India', Economic and Political Weekly, vol. 35, no. 5, pp. 273-82.

Mohanty, M. and Klau, M. (2004) 'Monetary Policy Rules in Emerging Economies: Issues and evidence’, BIS Working Paper, no. 149.

Obstfeld, M. and K. Rogoff (1996) Foundations of International Macroeconomics, Cambridge, MA and London: MIT Press.

Patel, U. and P. Srivastava (1997) 'Some Implication of Real Exchange Rate Targeting in India’, mimeo, Indian Council for Research on International Economic Relations.

RBI (Reserve Bank of India) (1993) Reserve Bank of India - Annual Report 1991-92, Mumbai.

RBI (2002) Reserve Bank of India Bulletin, Mumbai.

RBI (2004) Report on Currency and Finance, Mumbai.

Seyfried, W. and D. Bremmer (2003) 'Inflation Targeting as a Framework for Monetary Policy: A Cross-country analysis’, The Australian Economic Review, vol. 36, no. 3, pp. 291-99.

Sharma, A. (2004) Fiscal Deficits, Financial Crises and Adjustment in a Semi-Open Economy, unpublished Ph.D. dissertation, Australian National University.

Svensson, L. (1999) 'Inflation Targeting as a Monetary Policy Rule', Journal of Monetary Economics, vol. 43, no. 3, pp. 607-654.

Taylor, J. (1993) 'Discretion versus Policy Rules in Practice’, Carnegie-Rochester Conference Series on Public Policy, no. 39.

Taylor, J. (2002) 'The Monetary Transmission Mechanism and the Evaluation of Monetary Policy Rules’, in N. Loayza and K. Schmidt-Hebbel (eds), Monetary Policy: Rules and Transmission Mechanisms', Santiago: Central Bank of Chile.

White, W. (2004) 'Making Macro Prudential Concerns Operational', Speech Delivered at a Symposium on Financial Stability at Netherlands Bank.

Winters, A., McCulloch, N. and A. McKay (2002) 'Trade Liberalisation and Poverty: The empirical evidence’ Discussion Paper \#88, Department of Economics, University of Sussex at Brighton. 


\section{Appendix I:}

\section{Capital Controls: or why did India escape the East Asian crisis?}

It is instructive to compare India and the East Asian countries in 1996 (i.e. just before the East-Asian crisis of 1997). The first six columns of Table A1 indicate that, in most respects, India’s ‘fundamentals’ (fiscal balance, inflation, current account balance, non-performing assets, debt-exports ratio and debt-service ratio) were worse or no better than the crisiscountries. All these countries were on loose dollar peg and Indian was only marginally different from the rest in this regard except for the fact that India did not allow its real exchange rate to appreciate and was able to maintain its real exchange targeting posture.

The critical difference between India and the crisis-countries can be seen in the last two columns of Table A1. India managed to keep short-term debt under control, both in relation to total debt and in relation to foreign exchange reserves. Thus, India avoided the crisis by avoiding an unstable debt structure, an outcome that was the direct result of controls on debt-creating short-term inflows.

India was able to resist the pressure to adopt capital account convertibility essentially because of three reasons: first, the ideology of laissez faire is still not dominant in India, and second, foreign banks, which are normally a strong pressure group in favour of capital account convertibility, had a very small presence in the country. Finally, India was 'too big to be bullied' into adopting capital account convertibility by Wall Street, the IMF and the U.S. Treasury (Joshi and Sanyal 2004). 


\section{Table A1}

Various Countries: Indicators of Crisis-Vulnerability, 1996

\begin{tabular}{|c|c|c|c|c|c|c|c|c|}
\hline & $\begin{array}{c}\text { FB/GDP } \\
(\%)\end{array}$ & $\begin{array}{c}\Delta \mathrm{P} / \mathrm{P} \\
(\% \\
\text { p.a. })\end{array}$ & $\begin{array}{c}\text { CAB/XGS } \\
(\%)\end{array}$ & $\begin{array}{c}\text { NPA } \\
(\%)\end{array}$ & $\begin{array}{c}\text { NCEDT/XGS } \\
(\%)\end{array}$ & $\begin{array}{c}\text { TDS/XGS } \\
(\%)\end{array}$ & $\begin{array}{c}\text { SDT/EDT } \\
(\%)\end{array}$ & $\begin{array}{c}\text { SDT/RES } \\
(\%)\end{array}$ \\
\hline India & -9.0 & 9.0 & -11.7 & 17.3 & 103.6 & 21.2 & 5.3 & 27.1 \\
\hline Indonesia & -1.0 & 8.0 & -13.0 & 8.8 & 180.5 & 36.6 & 25.0 & 166.7 \\
\hline Korea & 0.0 & 4.9 & -14.6 & 4.1 & 82.0 & 9.4 & 49.4 & 192.7 \\
\hline Malaysia & 0.7 & 3.5 & -6.4 & 3.9 & 40.4 & 9.0 & 27.9 & 39.7 \\
\hline Philippines & 0.3 & 8.4 & -9.9 & n.a. & 80.1 & 13.4 & 19.9 & 67.9 \\
\hline Thailand & 0.7 & 5.8 & -19.5 & 7.7 & 110.9 & 12.6 & 41.5 & 97.4 \\
\hline
\end{tabular}

Notation

FB/GDP: Fiscal Balance as a proportion of GDP

$\triangle P / P:$ Rate of Consumer Price Inflation

CAB/XGS: Current Account Balance as a proportion of exports of goods and services

NPA: Non-performing Assets of commercial banks as a proportion of total advances

NCEDT/XGS: Non-Concessional External Debt as a proportion of exports of goods and services

TDS/XGS: Debt Service as a proportion of exports of goods and services

SDT/EDT: Short-term external debt as a proportion of total external debt

SDT/RES: Short-term external debt as a proportion of foreign exchange reserves

Sources

FB/GDP, NPA: Bank of International Settlements Annual Reports $1997 / 98$ and 1999/00 and Government of India, Economic Survey, 1999/00

CAB/XGS, NCEDT/XGS, TDS/XGS, SDT/EDT, SDT/RES: World Bank, Global Development Finance 1999

$\triangle$ P/P: I.M.F. International Financial Statistics 


\section{Appendix II: Details of VAR results}

Table A2: Diagnostics of VAR

$\begin{array}{lrrrrr}\text { Equation } & \text { Parms } & \text { RMSE } & \text { R-sq } & \text { chi2 } & \text { P>chi2 } \\ \text { Icpi } & 41 & 0.005067 & 0.9995 & 47287.61 & 0 \\ \text { Inarmon } & 41 & 0.014161 & 0.9987 & 17759.08 & 0 \\ \text { Ireer } & 41 & 0.015622 & 0.9755 & 917.5662 & 0 \\ \text { cmrate } & 41 & 4.19118 & 0.8296 & 111.9541 & 0 \\ \text { liip } & 41 & 0.031 & 0.9824 & 1281.867 & 0\end{array}$

Table A3: VAR Results

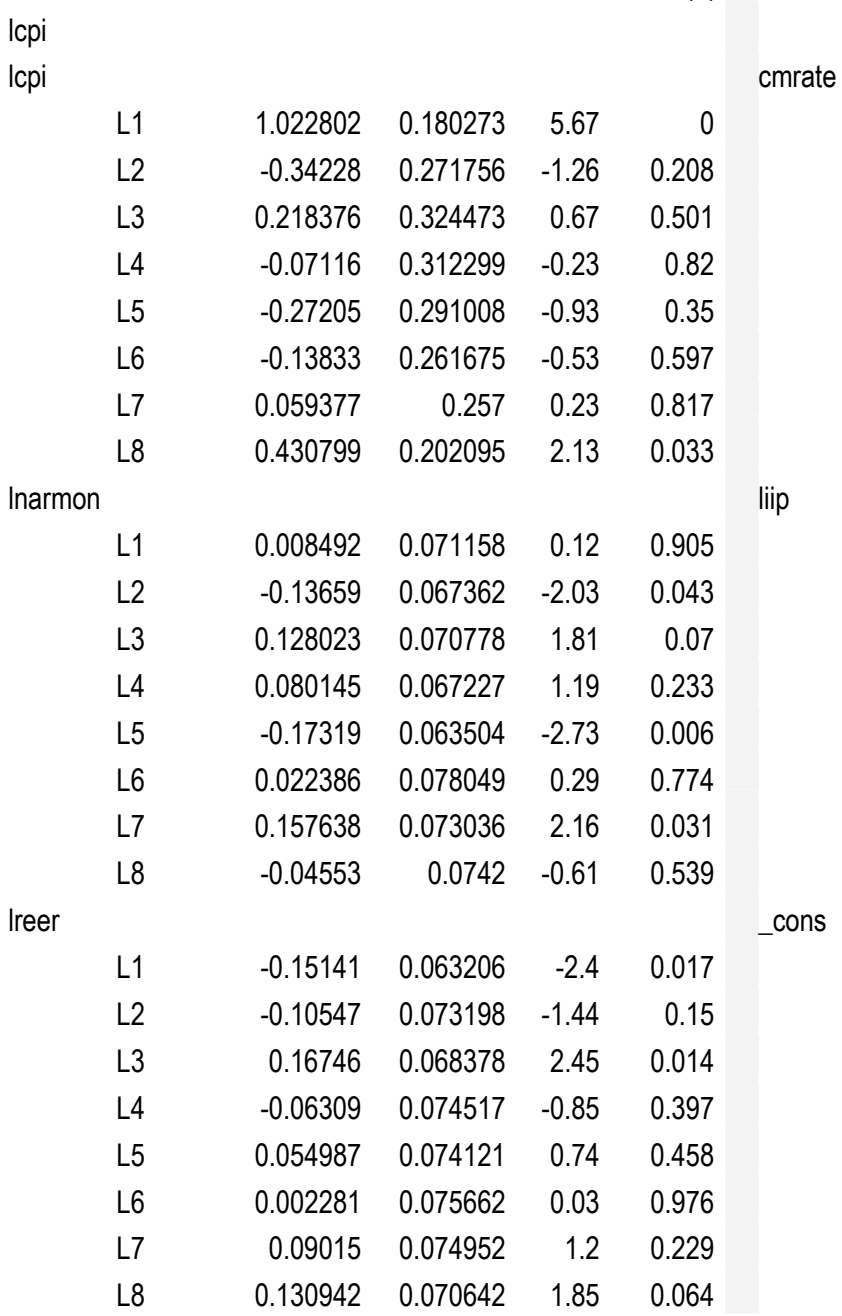

Coef. Std. Err. $\quad z \quad P>|z|$

$\begin{array}{lllll}\text { L1 } & -0.00081 & 0.000261 & -3.11 & 0.002\end{array}$

L2 $\quad-0.00018 \quad 0.000286 \quad-0.62 \quad 0.534$

$\begin{array}{lllll}\text { L3 } & -0.00059 & 0.000336 & -1.75 & 0.08\end{array}$

$\begin{array}{lllll}\text { L4 } & -0.00053 & 0.000388 & -1.36 & 0.175\end{array}$

$\begin{array}{lllll}\text { L5 } & 0.000224 & 0.000307 & 0.73 & 0.465\end{array}$

$\begin{array}{lllll}\text { L6 } & 0.000593 & 0.000319 & 1.86 & 0.063\end{array}$

$\begin{array}{lllll}\text { L7 } & 0.000382 & 0.00028 & 1.36 & 0.173\end{array}$

$\begin{array}{lllll}\text { L8 } & 0.000318 & 0.000242 & 1.32 & 0.188\end{array}$

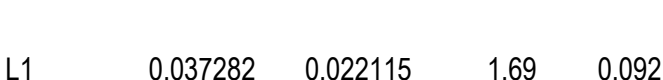

$\begin{array}{lllll}\text { L2 } & 0.027046 & 0.024897 & 1.09 & 0.277\end{array}$

$\begin{array}{lllll}\text { L3 } & 0.022736 & 0.026506 & 0.86 & 0.391\end{array}$

$\begin{array}{lllll}\text { L4 } & -0.00672 & 0.030558 & -0.22 & 0.826\end{array}$

$\begin{array}{lllll}\text { L5 } & -0.02104 & 0.031537 & -0.67 & 0.505\end{array}$

$\begin{array}{lllll}\text { L6 } & 0.024505 & 0.026951 & 0.91 & 0.363\end{array}$

$\begin{array}{lllll}\text { L7 } & -0.01157 & 0.030298 & -0.38 & 0.702\end{array}$

$\begin{array}{lllll}\text { L8 } & -0.00511 & 0.02749 & -0.19 & 0.853\end{array}$

$\begin{array}{llll}-0.79317 & 0.486902 & -1.63 & 0.103\end{array}$ 
Table A3: VAR Results (cont'd)

\begin{tabular}{|c|c|c|c|c|c|c|c|c|c|c|c|}
\hline & & Coef. & Std. Err. & \multicolumn{2}{|c|}{$z \quad P>|z|$} & & & Coef. & Std. Err. & z & $\mathrm{P}>|\mathrm{z}|$ \\
\hline \multicolumn{6}{|l|}{ Inarmon } & \multicolumn{6}{|l|}{ Ireer } \\
\hline Icpi & & & & & & Icpi & & & & & \\
\hline & L1 & -0.84606 & 0.503857 & -1.68 & 0.093 & & L1 & 0.312424 & 0.555816 & 0.56 & 0.574 \\
\hline & L2 & 0.828101 & 0.759548 & 1.09 & 0.276 & & L2 & -0.47987 & 0.837873 & -0.57 & 0.567 \\
\hline & L3 & 0.834757 & 0.906892 & 0.92 & 0.357 & & L3 & 0.540677 & 1.000412 & 0.54 & 0.589 \\
\hline & L4 & -0.41613 & 0.872865 & -0.48 & 0.634 & & L4 & -0.56463 & 0.962876 & -0.59 & 0.558 \\
\hline & L5 & -1.13119 & 0.813356 & -1.39 & 0.164 & & L5 & -1.04749 & 0.89723 & -1.17 & 0.243 \\
\hline & L6 & -0.24953 & 0.731373 & -0.34 & 0.733 & & L6 & 1.324968 & 0.806793 & 1.64 & 0.101 \\
\hline & L7 & -0.18897 & 0.718307 & -0.26 & 0.792 & & L7 & -0.96616 & 0.79238 & -1.22 & 0.223 \\
\hline & L8 & 0.431979 & 0.564848 & 0.76 & 0.444 & & L8 & 1.139542 & 0.623096 & 1.83 & 0.067 \\
\hline Inarmon & & & & & & Inarmon & & & & & \\
\hline & L1 & 0.093172 & 0.198884 & 0.47 & 0.639 & & L1 & -0.3822 & 0.219393 & -1.74 & 0.081 \\
\hline & L2 & 0.131256 & 0.188275 & 0.7 & 0.486 & & L2 & 0.385347 & 0.20769 & 1.86 & 0.064 \\
\hline & L3 & -0.03368 & 0.197823 & -0.17 & 0.865 & & L3 & 0.005713 & 0.218222 & 0.03 & 0.979 \\
\hline & L4 & 0.109221 & 0.187896 & 0.58 & 0.561 & & L4 & 0.045214 & 0.207272 & 0.22 & 0.827 \\
\hline & L5 & 0.550528 & 0.17749 & 3.1 & 0.002 & & L5 & 0.097733 & 0.195793 & 0.5 & 0.618 \\
\hline & L6 & 0.132951 & 0.218143 & 0.61 & 0.542 & & L6 & 0.065064 & 0.240638 & 0.27 & 0.787 \\
\hline & L7 & -0.36539 & 0.204134 & -1.79 & 0.073 & & L7 & -0.22361 & 0.225185 & -0.99 & 0.321 \\
\hline & L8 & 0.223191 & 0.207386 & 1.08 & 0.282 & & L8 & -0.026 & 0.228772 & -0.11 & 0.91 \\
\hline Ireer & & & & & & Ireer & & & & & \\
\hline & L1 & -0.10065 & 0.176659 & -0.57 & 0.569 & & L1 & 0.435343 & 0.194876 & 2.23 & 0.025 \\
\hline & L2 & -0.08238 & 0.204586 & -0.4 & 0.687 & & L2 & 0.050833 & 0.225683 & 0.23 & 0.822 \\
\hline & L3 & -0.10073 & 0.191114 & -0.53 & 0.598 & & L3 & -0.28885 & 0.210822 & -1.37 & 0.171 \\
\hline & L4 & -0.10341 & 0.208273 & -0.5 & 0.62 & & L4 & -0.0145 & 0.229751 & -0.06 & 0.95 \\
\hline & L5 & 0.160484 & 0.207165 & 0.77 & 0.439 & & L5 & -0.21787 & 0.228528 & -0.95 & 0.34 \\
\hline & L6 & -0.03941 & 0.211472 & -0.19 & 0.852 & & L6 & 0.30773 & 0.233279 & 1.32 & 0.187 \\
\hline & L7 & -0.04399 & 0.209487 & -0.21 & 0.834 & & L7 & 0.103859 & 0.231089 & 0.45 & 0.653 \\
\hline & L8 & 0.456653 & 0.197441 & 2.31 & 0.021 & & L8 & -0.11227 & 0.217802 & -0.52 & 0.606 \\
\hline cmrate & & & & & & cmrate & & & & & \\
\hline & L1 & 0.000473 & 0.000728 & 0.65 & 0.516 & & L1 & -0.00021 & 0.000803 & -0.26 & 0.798 \\
\hline & L2 & -0.00116 & 0.000799 & -1.45 & 0.148 & & L2 & -0.00152 & 0.000882 & -1.73 & 0.084 \\
\hline & L3 & -0.00211 & 0.00094 & -2.25 & 0.025 & & L3 & -0.00228 & 0.001037 & -2.19 & 0.028 \\
\hline & L4 & $-9.3 \mathrm{E}-05$ & 0.001085 & -0.09 & 0.932 & & L4 & -0.00039 & 0.001197 & -0.33 & 0.742 \\
\hline & L5 & -0.00154 & 0.000857 & -1.79 & 0.073 & & L5 & 0.000854 & 0.000946 & 0.9 & 0.367 \\
\hline & L6 & -0.00055 & 0.000891 & -0.62 & 0.536 & & L6 & -0.00064 & 0.000983 & -0.65 & 0.518 \\
\hline & L7 & 0.000686 & 0.000784 & 0.88 & 0.381 & & L7 & 0.00096 & 0.000864 & 1.11 & 0.267 \\
\hline & L8 & -0.001 & 0.000675 & -1.48 & 0.139 & & L8 & -0.00083 & 0.000745 & -1.12 & 0.264 \\
\hline liip & & & & & & liip & & & & & \\
\hline & L1 & 0.173314 & 0.061812 & 2.8 & 0.005 & & L1 & 0.059964 & 0.068186 & 0.88 & 0.379 \\
\hline & L2 & 0.29987 & 0.069585 & 4.31 & 0 & & L2 & -0.05232 & 0.076761 & -0.68 & 0.495 \\
\hline & L3 & 0.334331 & 0.074085 & 4.51 & 0 & & L3 & 0.008469 & 0.081724 & 0.1 & 0.917 \\
\hline & L4 & 0.298951 & 0.085408 & 3.5 & 0 & & L4 & -0.00751 & 0.094216 & -0.08 & 0.936 \\
\hline & L5 & 0.097806 & 0.088146 & 1.11 & 0.267 & & L5 & -0.0505 & 0.097236 & -0.52 & 0.603 \\
\hline & L6 & -0.08409 & 0.075328 & -1.12 & 0.264 & & L6 & -0.17463 & 0.083096 & -2.1 & 0.036 \\
\hline & L7 & -0.08179 & 0.084681 & -0.97 & 0.334 & & L7 & -0.23557 & 0.093413 & -2.52 & 0.012 \\
\hline & L8 & 0.002604 & 0.076833 & 0.03 & 0.973 & & L8 & -0.04333 & 0.084756 & -0.51 & 0.609 \\
\hline _cons & & -0.15897 & 1.360875 & -0.12 & 0.907 & _cons & & 4.472256 & 1.50121 & 2.98 & 0.003 \\
\hline
\end{tabular}


Table A3: VAR Results (cont'd)

\begin{tabular}{|c|c|c|c|c|c|c|c|c|c|c|}
\hline \multirow{2}{*}{\multicolumn{2}{|c|}{ cmrate }} & Coef. & Std. Err. & \multicolumn{2}{|c|}{$z P>|z|$} & \multirow[b]{2}{*}{ liip } & Coef. & Std. Err. & z & $\mathrm{P}>|\mathrm{z}|$ \\
\hline & & & & & & & & & & \\
\hline Icpi & & & & & & Icpi & & & & \\
\hline & L1 & 74.68881 & 149.1197 & 0.5 & 0.616 & L1 & -0.24782 & 1.102951 & -0.22 & 0.822 \\
\hline & L2 & -246.757 & 224.7929 & -1.1 & 0.272 & L2 & -1.99805 & 1.662661 & -1.2 & 0.229 \\
\hline & L3 & -18.0382 & 268.4003 & -0.07 & 0.946 & L3 & 2.030853 & 1.985199 & 1.02 & 0.306 \\
\hline & L4 & 335.3627 & 258.3298 & 1.3 & 0.194 & L4 & 3.598985 & 1.910714 & 1.88 & 0.06 \\
\hline & L5 & -213.441 & 240.7178 & -0.89 & 0.375 & L5 & -2.76368 & 1.780448 & -1.55 & 0.121 \\
\hline & L6 & 46.0124 & 216.4545 & 0.21 & 0.832 & L6 & -0.61246 & 1.600987 & -0.38 & 0.702 \\
\hline & L7 & 119.6916 & 212.5874 & 0.56 & 0.573 & L7 & -2.32011 & 1.572384 & -1.48 & 0.14 \\
\hline & L8 & -77.2012 & 167.1703 & -0.46 & 0.644 & L8 & 3.062954 & 1.236461 & 2.48 & 0.013 \\
\hline Inarmon & & & & & & Inarmon & & & & \\
\hline & L1 & -64.2943 & 58.86102 & -1.09 & 0.275 & L1 & -0.82552 & 0.43536 & -1.9 & 0.058 \\
\hline & L2 & 25.44524 & 55.72109 & 0.46 & 0.648 & L2 & 0.419107 & 0.412136 & 1.02 & 0.309 \\
\hline & L3 & 73.49611 & 58.54681 & 1.26 & 0.209 & L3 & -0.85543 & 0.433036 & -1.98 & 0.048 \\
\hline & L4 & -80.3636 & 55.609 & -1.45 & 0.148 & L4 & 1.343455 & 0.411307 & 3.27 & 0.001 \\
\hline & L5 & -25.5174 & 52.52931 & -0.49 & 0.627 & L5 & -0.17104 & 0.388529 & -0.44 & 0.66 \\
\hline & L6 & 83.2929 & 64.56079 & 1.29 & 0.197 & L6 & 0.543125 & 0.477518 & 1.14 & 0.255 \\
\hline & L7 & 32.03567 & 60.4147 & 0.53 & 0.596 & L7 & -1.24404 & 0.446852 & -2.78 & 0.005 \\
\hline & L8 & -23.4915 & 61.37725 & -0.38 & 0.702 & L8 & 1.170112 & 0.453972 & 2.58 & 0.01 \\
\hline Ireer & & & & & & Ireer & & & & \\
\hline & L1 & -135.6 & 52.28333 & -2.59 & 0.009 & L1 & -0.54472 & 0.386709 & -1.41 & 0.159 \\
\hline & L2 & 84.71294 & 60.54839 & 1.4 & 0.162 & L2 & -0.14526 & 0.447841 & -0.32 & 0.746 \\
\hline & L3 & 106.3868 & 56.56137 & 1.88 & 0.06 & L3 & -0.69716 & 0.418351 & -1.67 & 0.096 \\
\hline & L4 & -96.977 & 61.63972 & -1.57 & 0.116 & L4 & 1.046331 & 0.455913 & 2.3 & 0.022 \\
\hline & L5 & 101.6617 & 61.31174 & 1.66 & 0.097 & L5 & -0.68357 & 0.453487 & -1.51 & 0.132 \\
\hline & L6 & 3.061448 & 62.58629 & 0.05 & 0.961 & L6 & -0.14388 & 0.462914 & -0.31 & 0.756 \\
\hline & L7 & 5.528831 & 61.99894 & 0.09 & 0.929 & L7 & 0.203282 & 0.45857 & 0.44 & 0.658 \\
\hline & L8 & 17.43364 & 58.43399 & 0.3 & 0.765 & L8 & 0.78258 & 0.432202 & 1.81 & 0.07 \\
\hline cmrate & & & & & & cmrate & & & & \\
\hline & L1 & 0.144452 & 0.215456 & 0.67 & 0.503 & L1 & -0.00185 & 0.001594 & -1.16 & 0.247 \\
\hline & L2 & 0.212124 & 0.236495 & 0.9 & 0.37 & L2 & -0.00071 & 0.001749 & -0.41 & 0.683 \\
\hline & L3 & -0.32843 & 0.27818 & -1.18 & 0.238 & L3 & -0.00248 & 0.002058 & -1.21 & 0.227 \\
\hline & L4 & 0.348757 & 0.32124 & 1.09 & 0.278 & L4 & -0.00119 & 0.002376 & -0.5 & 0.618 \\
\hline & L5 & 0.371263 & 0.25371 & 1.46 & 0.143 & L5 & -0.00211 & 0.001877 & -1.13 & 0.26 \\
\hline & L6 & -0.00966 & 0.263765 & -0.04 & 0.971 & L6 & 0.00087 & 0.001951 & 0.45 & 0.656 \\
\hline & L7 & 0.323037 & 0.231899 & 1.39 & 0.164 & L7 & 0.004995 & 0.001715 & 2.91 & 0.004 \\
\hline & L8 & -0.12966 & 0.199769 & -0.65 & 0.516 & L8 & -0.00155 & 0.001478 & -1.05 & 0.293 \\
\hline liip & & & & & & liip & & & & \\
\hline & L1 & -0.3876 & 18.29357 & -0.02 & 0.983 & L1 & 0.065177 & 0.135307 & 0.48 & 0.63 \\
\hline & L2 & 17.39158 & 20.59418 & 0.84 & 0.398 & L2 & 0.111749 & 0.152323 & 0.73 & 0.463 \\
\hline & L3 & -21.326 & 21.92579 & -0.97 & 0.331 & L3 & 0.285742 & 0.162172 & 1.76 & 0.078 \\
\hline & L4 & -10.8828 & 25.27715 & -0.43 & 0.667 & L4 & -0.1691 & 0.18696 & -0.9 & 0.366 \\
\hline & L5 & -4.76913 & 26.08732 & -0.18 & 0.855 & L5 & 0.097485 & 0.192953 & 0.51 & 0.613 \\
\hline & L6 & 21.23645 & 22.29369 & 0.95 & 0.341 & L6 & -0.11812 & 0.164893 & -0.72 & 0.474 \\
\hline & L7 & -24.273 & 25.06177 & -0.97 & 0.333 & L7 & -0.36354 & 0.185367 & -1.96 & 0.05 \\
\hline & L8 & -1.63537 & 22.7392 & -0.07 & 0.943 & L8 & -0.49905 & 0.168189 & -2.97 & 0.003 \\
\hline _cons & & -544.888 & 402.7593 & -1.35 & 0.176 & _cons & 0.80628 & 2.978974 & 0.27 & 0.787 \\
\hline
\end{tabular}


Table A4: Testing for Cointegration

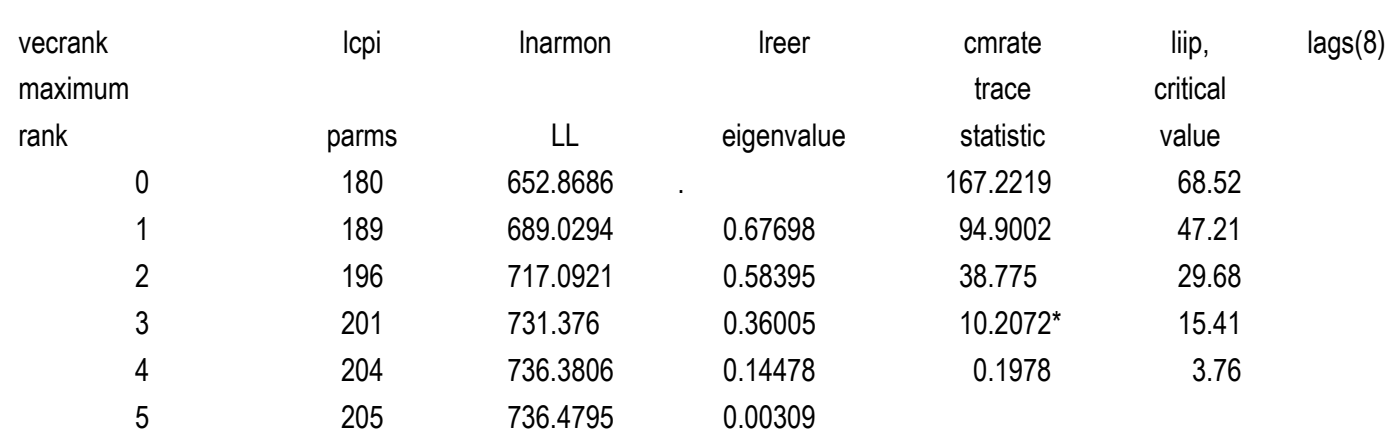

Table A5: Disgnostics ofVECM

\begin{tabular}{|c|c|c|c|c|c|}
\hline Sample: $\quad 9$ & 72 & No. of & obs & $=$ & 64 \\
\hline & & $\mathrm{AIC}$ & & $=$ & -16.5743 \\
\hline Log likelihood = & 731.376 & HQIC & & $=$ & -13.9032 \\
\hline Det(Sigma_ml) = & $8.16 \mathrm{E}-17$ & SBIC & & $=$ & -9.79401 \\
\hline Equation & Parms & RMSE & R-sq & chi2 & $P>c h i 2$ \\
\hline D_Icpi & 39 & 0.004974 & 0.9135 & 253.4932 & 0 \\
\hline D_Inarmon & 39 & 0.01395 & 0.8808 & 177.3249 & 0 \\
\hline D_Ireer & 39 & 0.015145 & 0.716 & 60.50188 & 0.0152 \\
\hline D_cmrate & 39 & 4.06172 & 0.8136 & 104.7663 & 0 \\
\hline D_lip & 39 & 0.030209 & 0.9287 & 312.385 & 0 \\
\hline
\end{tabular}

Table A6: Significance of Cointegrating Vectors

Cointegrating equations

$\begin{array}{cccc}\text { Equation } & \text { Parms } & \text { chi2 } & \text { P>chi2 } \\ \text { _ce1 } & 2 & 885.5437 & 0 \\ \text { _ce2 } & 2 & 309.8379 & 0 \\ \text { _ce3 } & 2 & 252.7762 & 0\end{array}$


Table A7: Cointegrating Vectors (Normalized)

beta

Coef.

Std. Err.

z

$\mathrm{P}>|\mathrm{z}|$

ce1

Icpi $\quad 1$

Inarmon $\quad 3.47 \mathrm{E}-17$

Ireer $\quad 1.67 \mathrm{E}-16$

cmrate $\quad 0.016328$

liip $\quad-0.90026$

cons $\quad-0.93483$

_ce2

Icpi (dropped)

Inarmon 1

Ireer (dropped)

cmrate

liip $\quad-2.12823$

_cons $\quad 0.534378$

_ce3

Icpi $\quad 5.55 \mathrm{E}-17$

Inarmon $\quad 2.08 \mathrm{E}-17$

Ireer

cmrate

liip

_cons
0.002172

0.034785

7.52

$-25.88$

$-5.21$

$-17.59$

0.121004

15.58
0.00188

0.030104

$-6.56834$

0

0 